\title{
Callovian (Middle Jurassic) cyclostome bryozoans from the Zalas Quarry, southern Poland
}

\author{
Michat ZATOŃ, URSZULA HARA, PAUL D. TAYLOR \& MICHAt KROBICKI
}

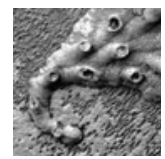

\begin{abstract}
The specimen-rich and diverse bryozoan fauna from the Callovian hardground at Zalas Quarry in southern Poland is described. Twenty-two taxa of cyclostomes are recorded, of which three species are proposed as new: Microeciella calloviana, Reptomultisparsa viskovae and Mesonopora walteri. Due to preservational problems and an insufficient number of fertile colonies, species-level determination of fourteen forms was not possible. The most common bryozoans present are sheet-like bereniciform colonies, with uniserial runners and oligoserial ribbons less abundant. The number of the Callovian taxa present in the Zalas Quarry is very similar to the Upper Bathonian-Lower Callovian bryozoan assemblage from the classic locality of Balin in southern Poland. Taking the strictly Callovian age into account, the Zalas assemblage is the most diverse for that age ever noted. $\bullet$ Key words: Bryozoa, Cyclostomata, Callovian, Jurassic, Poland.
\end{abstract}

ZATOŃ, M., HARA, U., TAYLOR, P.D. \& KROBICKI, M. 2013. Callovian (Middle Jurassic) cyclostome bryozoans from the Zalas Quarry, southern Poland. Bulletin of Geosciences 88(4), 837-863 (19 figures). Czech Geological Survey, Prague. ISSN 1214-1119. Manuscript received July 8, 2013; accepted in revised form September 5, 2013; published online October 21, 2013; issued October 31, 2013.

\begin{abstract}
Michat Zaton (corresponding author), University of Silesia, Faculty of Earth Sciences, Będzińska Street 60, PL-41-200 Sosnowiec, Poland; mzaton@wnoz.us.edu.pl•Urszula Hara, Polish Geological Institute - National Research Institute, Rakowiecka 4, PL-00-975 Warszawa, Poland; urszula.hara@ pgi.gov.pl•Paul D. Taylor, Natural History Museum, Department of Earth Sciences, Cromwell Road, London SW7 5BD, United Kingdom; p.taylor@nhm.ac.uk • Michat Krobicki, Polish Geological Institute - National Research Institute; Upper Silesian Branch, Królowej Jadwigi 1, PL-41-200 Sosnowiec, Poland, \& AGH University of Science \& Technology, Department of General Geology and Geotourism, al. Mickiewicza 30, PL-30-059 Kraków, Poland; michal.krobicki@pgi.gov.pl, krobicki@geol.agh.edu.pl
\end{abstract}

The Middle Jurassic was a significant time in the evolutionary radiation of the cyclostome bryozoans, which reached their maximum diversity for the Jurassic in the Bathonian (Taylor \& Larwood 1990, Jablonski et al. 1997, Taylor \& Ernst 2008). This peak is due mainly to the exceptional diversity of cyclostomes in Calvados, northern France, particularly the sponge reef and hardground settings of the Caillasse de la Basse Ecarde at St Aubin-sur-Mer, where 33 species were recorded by Walter (1970). Research on cyclostome bryozoans from other sites is needed to test whether the Bathonian diversity peak is a real phenomenon, or merely reflects the exposure of suitable facies. Although published data on Jurassic cyclostome bryozoans is still scarce, recent progress towards understanding their diversity has been made in both North America (see Taylor \& Wilson 1999) and central and eastern Europe (see Hara \& Taylor 1996, 2009; Taylor 2009; Viskova 2006, 2007, 2008, 2009; Zatoń \& Taylor 2009, 2010).

The cyclostome bryozoans of the Upper Bathonian-Lower Callovian of southern Poland were first systematically studied in the $19^{\text {th }}$ century by Reuss (see Reuss 1867) from the deposits at the classic locality of Balin. The material described by Reuss from Balin was recently revised by Taylor (2009), who described a total of twenty-three taxa, among which eight were considered to be new. This study emphasized the morphology of both the gonozooids and pseudopores as important taxonomic characters. Other studies undertaken in the past few years on the Middle Jurassic (Late Bajocian and Bathonian) cyclostomes of southern Poland have revealed the presence of twenty-nine species belonging to nine genera (Zatoń \& Taylor 2009, 2010). A few recent publications on younger faunas of cyclostomes from the Polish Upper Jurassic have enhanced our understanding of the systematics and distributional patterns of these bryozoans (see Hara 2007; Hara \& Taylor 1996, 2009).

The current paper provides the first detailed systematic description of the Callovian cyclostome bryozoans from the Zalas Quarry near Kraków in the southern Poland, describing twenty-two taxa belonging to eleven genera. Palaeoecological factors are discussed ( $c f$. Hara 2007), such as the substrate type and colony growth-forms of the bryozoans that colonized hard, mostly organic shelly substrates, often represented by shells of the limid bivalve Ctenostreon proboscideum (Sowerby). 
As the Balin cyclostomes revised by Taylor (2009) come from condensed deposits of Late Bathonian-Early Callovian and probably also earliest Middle Callovian age (Mangold et al. 1996), the new fauna described here not only supplements this data, but also significantly enlarges our knowledge about cyclostome bryozoans of strictly Callovian age.

\section{Material and methods}

Material and its provenance. - The Callovian cyclostome bryozoans were found encrusting various types of fossils (bivalve shells, belemnite rostra, cephalopod moulds) resting on the hardground surface located in the Zalas Quarry, situated about $8 \mathrm{~km}$ south of Krzeszowice and $30 \mathrm{~km}$ west of Kraków in southern Poland (Fig. 1A, B). The hardground developed on the top of sandy crinoidal limestones of Lower Callovian age (koenigi and calloviense zones) during a period of non-deposition and associated chemical and physical erosion. Features of the hardground are well expressed in the presence of limonitic coatings and abundant encrusters and borers (Giżejewska \& Wieczorek 1976, Dembicz \& Praszkier 2007, Zatoń et al. 2011). It is considered that the period of non-deposition during hardground formation spanned the Middle Callovian (jason and nearly all of the coronatum chrons, see Giżejewska \& Wieczorek 1976) and part of the Late Callovian (Matyja 2006, Dembicz \& Praszkier 2007). Depressions in the top of the crinoidal limestone are also filled with a nodular deposit (a limestone with nodular structure, termed nodular limestones by Giżejewska \& Wieczorek (1976), consisting of clasts and fossils with ferruginous coatings and encrustations, derived from the underlying crinoidal limestones. Their chemical corrosion and erosional truncation also indicate that they were redeposited (Giżejewska \& Wieczorek 1976, Dembicz \& Praszkier 2007). The hardground and nodular limestones are overlain by an uppermost Callovian (lamberti Zone) stromatolitic layer (Giżejewska \& Wieczorek 1976, Matyja 2006, Dembicz \& Praszkier 2007). The entire Callovian section is a deepening-upwards sequence from clastic and carbonate-clastic to strictly pelagic carbonates, and most probably originated in an open outer shelf environment ( $c f$. Matyja 2006).

Although a variety of fossils are encrusted, most of the bryozoans encrust shells of the large limid bivalve Ctenostreon proboscideum (Sowerby) (Fig. 1C, D), which also hosted other diverse and abundant encrusters and borings (see Zatoń et al. 2011 for details). The encrusted bivalves were collected from the uppermost part of the crinoidal limestones - hardground surface.

Methods. - Each encrusted fossil was inspected under a binocular microscope and every bryozoan colony marked.
Well-preserved uniserial (stomatoporids) and oligoserial (Oncousoecia) colonies, as well as all bereniciform colonies that were fertile (i.e., possessed gonozooids), were sawn off the shell substrate, cleaned ultrasonically, and examined in an uncoated state using a LEO 1455VP low vacuum scanning electron microscope housed at the Natural History Museum in London (NHMUK), or a Philips XL 30 environmental scanning electron microscope housed at the Faculty of Earth Sciences in Sosnowiec, Poland. Images were generated using back-scattered electrons (BSE detector).

It must be stressed that although ultrasonically cleaned, many colonies were still coated by a ferruginous crust that obscured some morphological details. Some bereniciform colonies additionally had eroded gonozooids, which allowed generic identification but hampered species-level determination due to the lack of key features such as the position, size and shape of the ooeciopore.

In the present paper the term gonozooid is used for the entire fertile zooid whereas brood chamber refers to its distal, dilated part with a densely pseudoporous frontal wall in which the embryos were actually brooded.

The specimens are housed at the Faculty of Earth Sciences, Sosnowiec, with registration numbers prefaced by GIUS 8-3589.

\section{Systematic palaeontology}

Order Cyclostomata Busk, 1852

Family Stomatoporidae Pergens \& Meunier, 1886

\section{Genus Stomatopora Bronn, 1825}

Type species. - Alecto dichotoma Lamouroux, 1821, by monotypy.

\section{Stomatopora cf. dichotomoides (d'Orbigny, 1850)}

Figure $2 \mathrm{~A}-\mathrm{C}$

Material. - Many variably preserved colonies on several bivalve shells (GIUS 8-3589). One colony, GIUS 8-3589-Z10/1was selected for SEM.

Description. - Colony encrusting, uniserial, the single scanned example consisting of five zooids forming a single branch, not ramifying (Fig. 2A); branch curved near to the base of the third zooid, the three youngest zooids growing alongside a serpulid tube. Ancestrula long, about $400 \mu \mathrm{m}$ (including protoecium), bending by about $140^{\circ}$ at midlength. Protoecium a low dome, broad compared to proximal part of ancestrular tube, about $130 \mu \mathrm{m}$ in transverse diameter, subcircular in outline, the proximal edge containing a few embayments; surface well preserved, smooth 

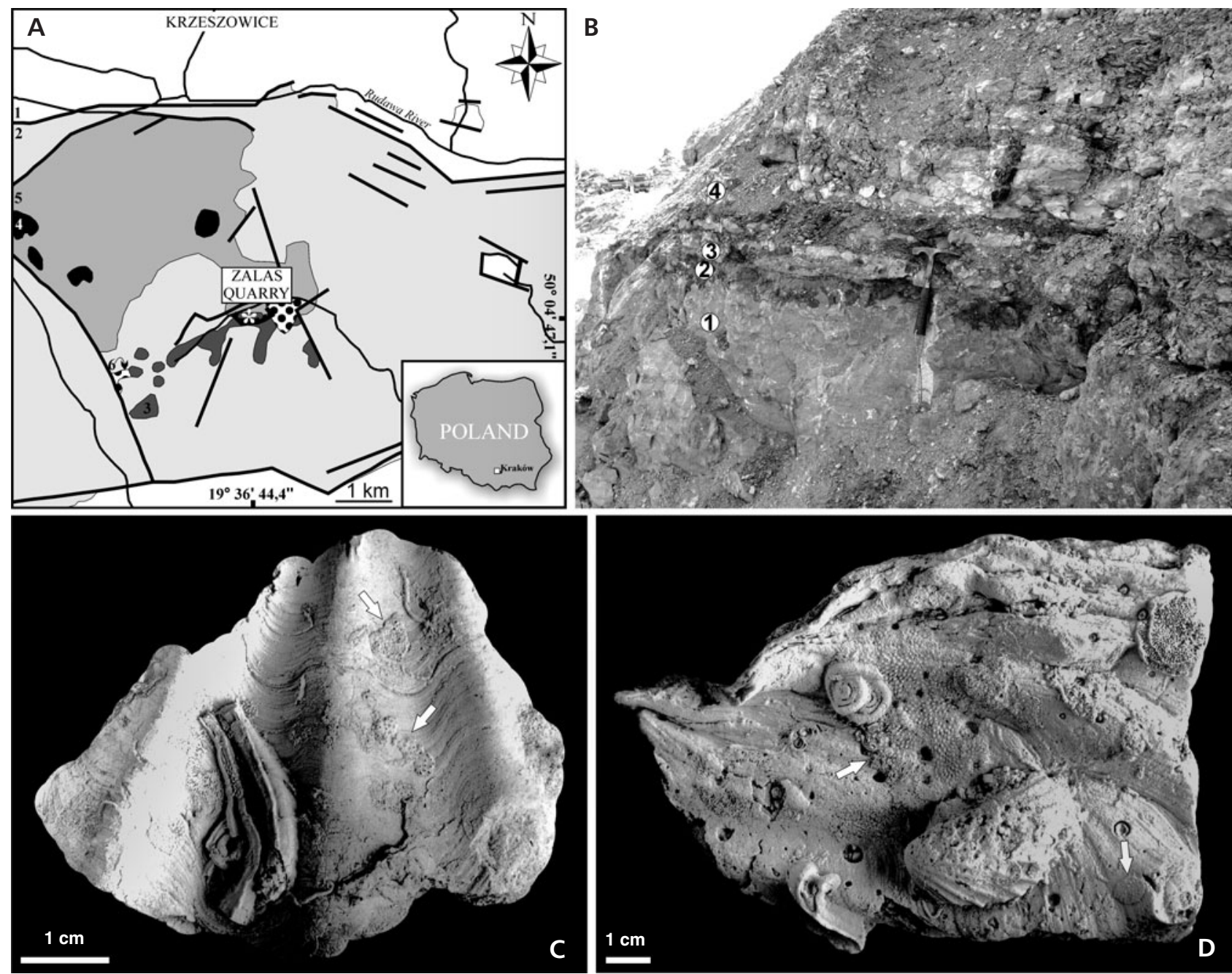

Figure 1. Locality, section sampled and material. • A - geological sketch-map of the environs of Krzeszowice with location of Zalas Quarry indicated by an asterisk (from Zatoń et al. 2011 and simplified after Nawrocki et al. 2007); 1 - Cenozoic mudstones, 2 - Mesozoic deposits, 3 - Permian rhyodacite domes and rhyolitic, trachytic and andesitic dykes, 4 - Permo-Carboniferous basaltic lavas and trachyandesite sills, 5 - Upper Carboniferous conglomerates, 6 - Lower Carboniferous mudstones. - B - Middle Jurassic section exposed at the Zalas Quarry, 1 - Lower Callovian crinoidal limestones, 2 - hardground (sampled interval) of presumably Middle-Late Callovian age, 3 - bed with stromatolites and oncolites of latest Callovian age, 4 - Lower Oxfordian limestones. $\bullet$ C, D - sampled Ctenostreon bivalve shells showing intensive encrustation and boring by various sclerobionts. Cyclostome bryozoans colonies are indicated by arrows. Scale bars equal $1 \mathrm{~cm}$.

without any obvious pseudopores but pierced by an irregular hole $20 \mu \mathrm{m}$ in diameter, possibly a boring (Fig. 2B). Ancestrular tube initially $60 \mu \mathrm{m}$ in width, enlarging to $80 \mu \mathrm{m}$ distally, tube marked by transverse growth checks; aperture broken, about $60 \mu \mathrm{m}$ in transverse diameter. Budded autozooids with apertures about $80 \mu \mathrm{m}$ in transverse diameter, the youngest zooid measuring $800 \mu \mathrm{m}$ long by about $200 \mu \mathrm{m}$ wide. Pseudopores widely scattered, apparently lacking from some parts of the frontal wall, teardrop-shaped, pointed distally (Fig. 2C), about $7 \mu \mathrm{m}$ long by $4 \mu \mathrm{m}$ wide.

Remarks. - For an abbreviated synonymy of S. dichotomoides, see Hara \& Taylor (2009). While the zooid dimensions of this Zalas form match those of S. dichotomoides as interpreted by Hara \& Taylor (2009) from the Polish Lower Kimmeridgian, the pseudopores are much sparser. Unfortunately, no information is available about these structures in type or topotype material of this species from the French Bajocian.

\section{Stomatopora cf. recurva Waagen, 1867}

Figure 2D-F

Material. - Many variably preserved colonies on bivalve shells. Three colonies were selected for SEM: GIUS 8-3589-Z7/4, GIUS 8-3589-Z7/5 and GIUS 8-3589-Z3b. 

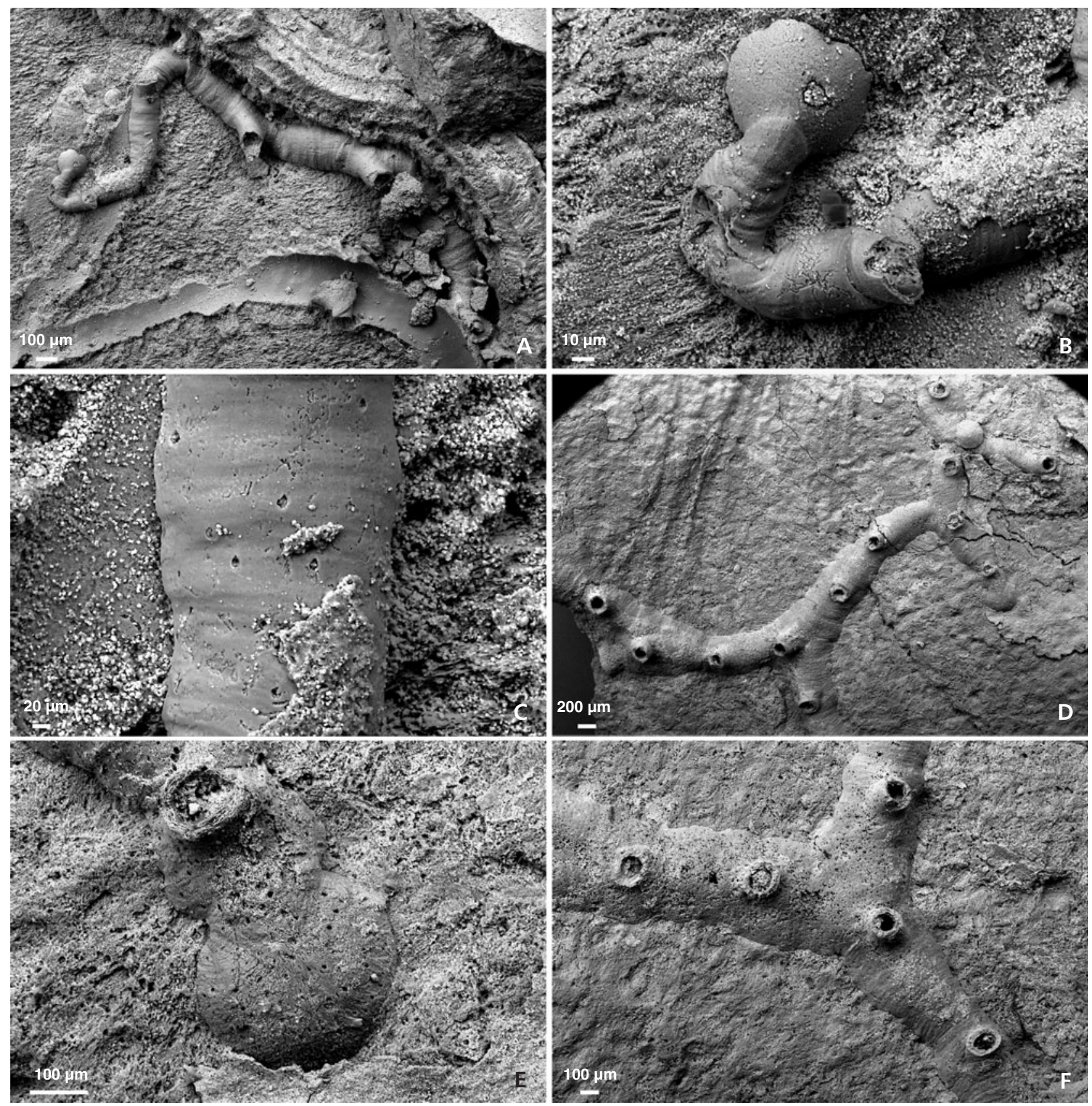

Figure 2. Stomatoporid cyclostome bryozoans from the Callovian hardground of the Zalas Quarry, southern Poland. - A-C - Stomatopora cf. dichotomoides (d'Orbigny, 1850), GIUS 8-3589-Z10/1. A - initial, uniserial part of the colony; B - ancestrula with disc-shaped protoecium and curved distal tube; C - autozooid frontal wall with scattered pseudopores. - D-F - Stomatopora cf. recurva Waagen, 1867, GIUS 8-3589-Z7/4. D - early astogeny; E - ancestrula with pseudoporous protoecium; F - dichotomous bifurcation showing autozooid frontal walls.

Description. - Colony encrusting, uniserial/pseudouniserial, branches bifurcating every second or third zooid, the two daughter zooids remaining linked for up to a third of their lengths after bifurcation (Fig. 2D). First bifurcation at $c a 120^{\circ}$, second at $90^{\circ}$, later bifurcations ranging down to $c a 60^{\circ}$. Ancestrula short, straight, stout, $550 \mu \mathrm{m}$ long (including protoecium), up to $280 \mu \mathrm{m}$ wide; aperture subcircular, transverse diameter $90 \mu \mathrm{m}$. Protoecium a low dome, $360 \mu \mathrm{m}$ in transverse diameter, with longitudinally elliptical, moderately abundant pseudopores scattered over the smooth surface (Fig. 2E). Budded autozooids large, stout, about $800 \mu \mathrm{m}$ long by $600 \mu \mathrm{m}$ maximum width (branch width), with subcircular or transversely elliptical apertures $100 \mu \mathrm{m}$ long by $100-130 \mu \mathrm{m}$ wide (Fig. 2F). Pseudopores subcircular, ca $10 \mu \mathrm{m}$ in diameter (Fig. 2E). 

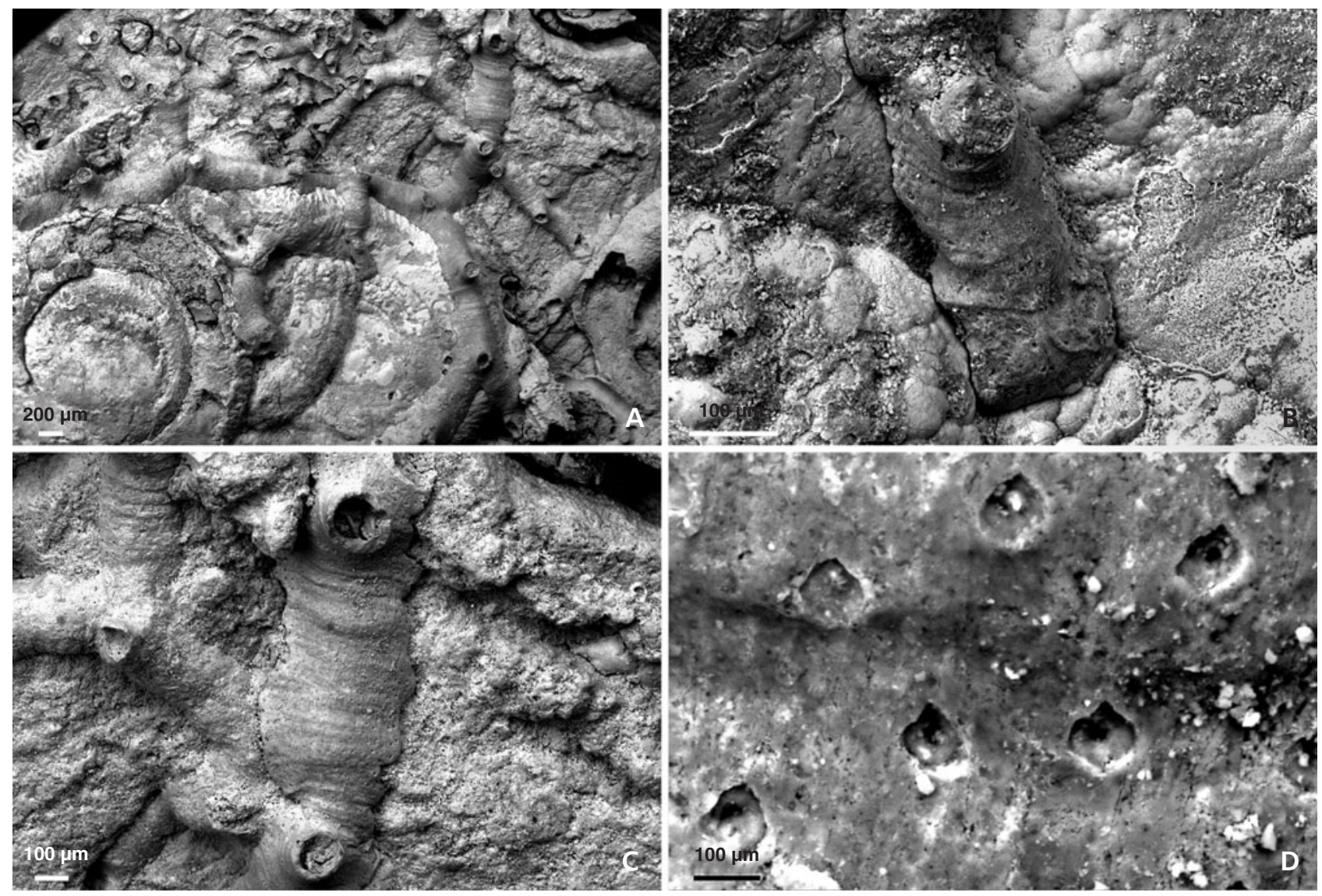

Figure 3. Stomatopora sp. from the Callovian hardground of the Zalas Quarry, southern Poland, GIUS 8-3589-Z3/9. • A - colony associated with serpulid tubes; B - ancestrula with narrow protoecium; C - autozooid frontal walls; D - pseudopores.

Remarks. - This taxon is probably pseudouniserial, as indicated by the comparatively large width of the branches and change in slope along the branch edges, implying that the median zooid is flanked by the proximal parts of the next distal zooid in series, as well as the delayed separation of zooids after each bifurcation. The large size of the zooids and width of the branches allows the form to be compared with $S$. recurva Waagen, which was recorded from the nearby locality of Balin by Taylor (2009). As with the other established species of Stomatopora, however, critical details of the pseudopores and early astogeny in the German type material of S. recurva are unknown, hampering the precise characterization of S. recurva.

\section{Stomatopora sp.}

Figure 3A-D

Material. - One colony, GIUS 8-3589-Z3/9.

Description. - Colony encrusting, uniserial, branches bifurcating every alternate zooid with angles of bifurcation decreasing from an initial $180^{\circ}$ to less than $90^{\circ}$ by the third generation of branching (Fig. 3A). Ancestrula short, about $370 \mu \mathrm{m}$ long (including protoecium), straight, up to $170 \mu \mathrm{m}$ in maximum width; aperture subcircular, $80 \mu \mathrm{m}$ in diameter. Ancestrular tube almost as wide as protoecium. Protoecium comparatively flat, about $180 \mu \mathrm{m}$ in transverse diameter, the surface rugose (Fig. 3B), facetted; pseudopores irregularly scattered, about $5 \mu \mathrm{m}$ in diameter, subcircular to teardrop-shaped and pointed distally. Budded autozooids up to $1100 \mu \mathrm{m}$ long by $440 \mu \mathrm{m}$ wide, with subcircular apertures 130-140 $\mu \mathrm{m}$ wide (Fig. 3C). Pseudopores regularly spaced, about $30 \mu \mathrm{m}$ apart (centre to centre), teardropshaped with pointed distal ends, with a sunken, iris-like ring of calcification defining a central opening 2-3 $\mu \mathrm{m}$ in diameter (Fig. 3D).

Remarks. - A third, unnamed taxon of Stomatopora from Zalas has autozooids intermediate in size (width) between those of $S$. cf. dichotomoides and $S$. cf. recurva. The ancestrula is distinctive in possessing a flat protoecium with sparse pseudopores, while at least some of the pseudopores on the budded zooids have a distinctive iris-like constriction. 
Family Oncousoeciidae Canu, 1918

\section{Genus Oncousoecia Canu, 1918}

Type species. - Tubulipora lobulata Canu, 1918 (see Taylor \& Zatoń 2008).

\section{Oncousoecia sp. 1}

Figure $4 \mathrm{~A}-\mathrm{C}$

Material. - Many ( ca 34), variably preserved and ?infertile colonies encrusting several bivalve shells (GIUS 8-3589), of which four were selected for SEM: GIUS 8-3589-30/1, GIUS 8-3589-Z5/1, GIUS 8-3589-M3, GIUS 8-3589-M15a/1.

Description. - Colony encrusting, pluriserial, comprising bifurcating, ribbon-like branches, with 2-7 autozooids across the width of the branch; kenozooids developed on sloping lateral edges of at least some branches (Fig. 4A). Ancestrula about $300 \mu \mathrm{m}$ long with a protoecium $180 \mu \mathrm{m}$ in transverse diameter; surface too poorly preserved in the single example to reveal pseudopore shape or patterning. Autozooids elongate, frontal walls convex, about 500-1000 $\mu \mathrm{m}$ long by $300 \mu \mathrm{m}$ wide; apertures subcircular or longitudinally elliptical, $c a 100 \mu \mathrm{m}$ in diameter; peristome short to moderate in length, distally tapering and inclined at $60^{\circ}$ or more to colony surface. Pseudopores elongate, slit-like, about $15 \mu \mathrm{m}$ long, becoming longitudinally elliptical in weathered specimens (Fig. 4C). Gonozooid not unequivocally identified, only a longitudinally ovate swelling observed in one specimen being a possible gonozooid (Fig. 4B).

Remarks. - The lack of an unequivocal gonozooid precludes species-level identification of this form. However, it is not the same species described among the Reuss material from Balin by Taylor (2009), which has significantly larger zooids (up to $1880 \mu \mathrm{m}$ long by $330-400 \mu \mathrm{m}$ wide).

\section{Oncousoecia sp. 2}

Figure 4D-F

Material. - One fertile but incomplete colony encrusting a bivalve shell: GIUS 8-3589-Z3/2a.

Description. - Colony encrusting, pluriserial, comprising, ribbon-like branches (presumably bifurcating), 2-3 autozooids wide (Fig. 4D). Ancestrula and early astogenetic stages not observed. Autozooids large, elongate, frontal walls convex, about $800-1300 \mu \mathrm{m}$ long by $300 \mu \mathrm{m}$ wide, zooecial boundaries well defined by grooves; apertures subcircular, 140-170 $\mu \mathrm{m}$ in diameter; peristome short to moderate in length. Pseudopores circular, about $7 \mu \mathrm{m}$ in diameter, spaced approximately $20 \mu \mathrm{m}$ apart (Fig. 4F). Gonozooid longitudinally ovate (Fig. 4E), brood chamber $>600 \mu \mathrm{m}$ long by $500 \mu \mathrm{m}$ wide, densely pseudoporous, the spacing between pseudopores roughly equivalent to their diameters; ooeciopore longitudinally elliptical, considerably smaller than an autozooidal aperture, about $70 \mu \mathrm{m}$ long by $60 \mu \mathrm{m}$ wide.

Remarks. - This form has appreciably larger apertures than Oncousoecia sp. 1 and the pseudopores are circular rather than slit-like. Despite being fertile, the material is inadequate to allow a reliable comparison with established species of Oncousoecia, which in any case are poorly characterized in the literature. The species of Oncousoecia from Balin, apart from being represented by infertile colonies, differs in having longitudinally elliptical pseudopores (Taylor 2009).

\section{Genus Microeciella Taylor \& Sequeiros, 1982}

Type species. - Microeciella beliensis Taylor \& Sequeiros, 1982 by original designation.

\section{Microeciella calloviana sp. nov.} Figure 5A-F

Types. - Holotype: GIUS 8-3589-Z5/2 (Fig. 5A-D); paratypes: GIUS 8-3589-M6 (Fig. 5E), GIUS 8-3589-M7 (Fig. 5F), GIUS 8-3589-Z3a/01.

Type locality. - Zalas Quarry, southern Poland.

Type horizon. - Callovian hardground, Middle Jurassic.

Etymology. - After Callovian, the age of the species described.

Material. - Four colonies encrusting bivalve shells: GIUS 8-3589-Z5/2, GIUS 8-3589-M6, GIUS 8-3589-M7, GIUS 8-3589-Z3a/01.

Measurements. - Autozooid frontal wall length: 570-670 $\mu \mathrm{m}$; autozooid frontal wall width: 140-160 $\mu \mathrm{m}$; longitudinal apertural diameter: $87-110 \mu \mathrm{m}$; transverse apertural diameter: 87-100 $\mu \mathrm{m}$; gonozooid total length: $1030 \mu \mathrm{m}$; brood chamber length: 530-630 $\mu \mathrm{m}$; gonozooid width: 600-820 $\mu \mathrm{m}$; ooeciopore length: $30 \mu \mathrm{m}$; ooeciopore width: $50 \mu \mathrm{m}$; pseudopore width: $6-8 \mu \mathrm{m}$.

Diagnosis. - Microeciella species having a sheet-like colony possessing elongate autozooids of a narrow width range and gonozooids with ovoidal brood chamber with terminally located ooeciopores. Pseudopores circular to wide teardrop-shaped. 

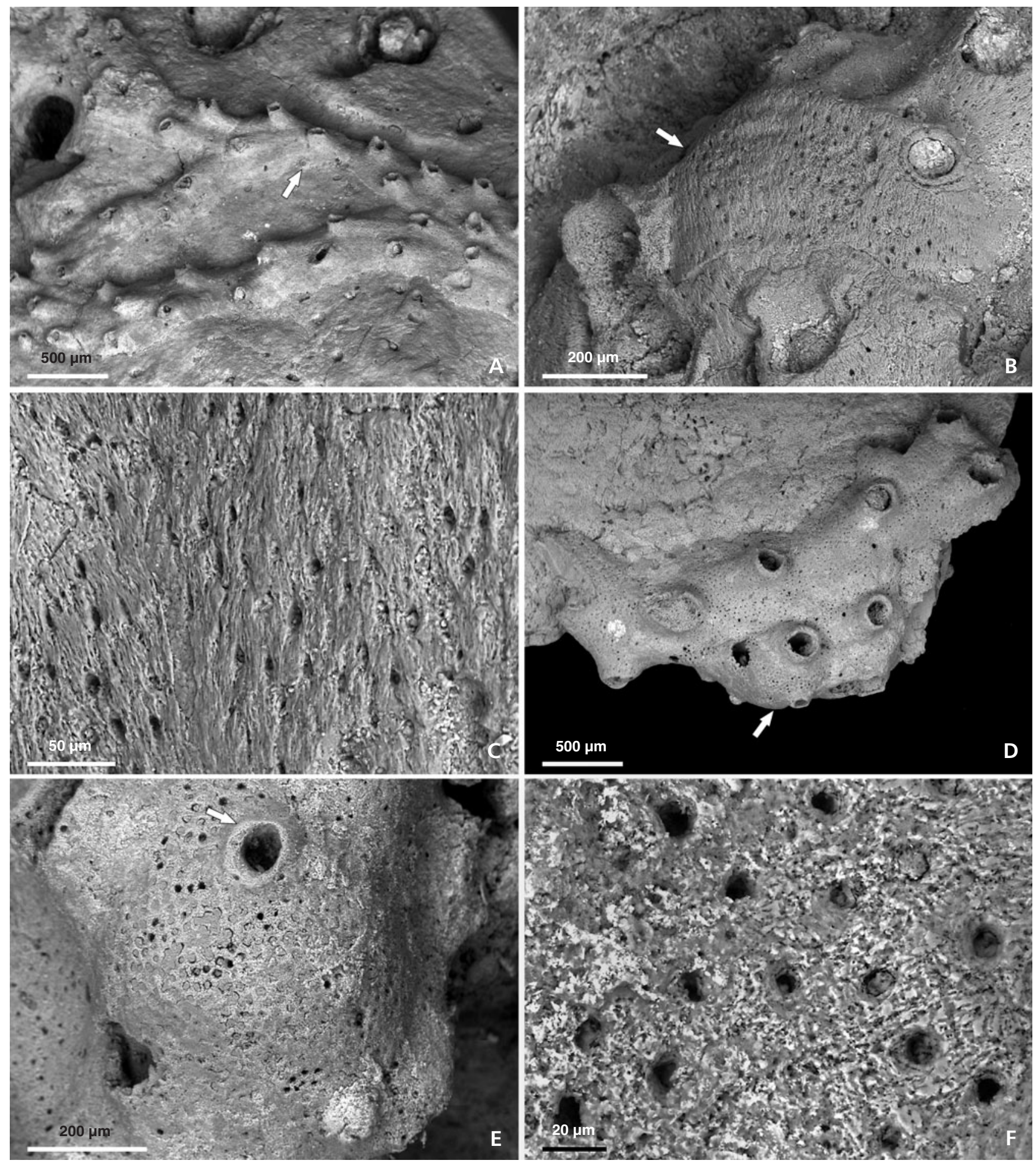

Figure 4. Oncousoeciid cyclostome bryozoans from the Callovian hardground of the Zalas Quarry, southern Poland. • A-C - Oncousoecia sp. 1, GIUS 8-3589-M15a/1. A - oligoserial colony with kenozooid on sloping lateral edge (arrowed); B - probable gonozooid (arrowed); C - pseudopores. - D-F - Oncousoecia sp. 2, GIUS 8-3589-Z3/2a. D - colony fragment with preserved gonozooid (arrowed); E - brood chamber with subterminal ooeciopore (arrowed); F-pseudopores.

Description. - Colony encrusting, sheet-like, bereniciform, multiserial, unilamellar (Fig. 5A). Autozooids elongate with convex frontal walls; zooidal boundaries distinct, marked by shallow grooves. Peristomes short, tapering distally. Apertures semicircular to longitudinally elongate, some closed by terminal diaphragms located a little beneath 

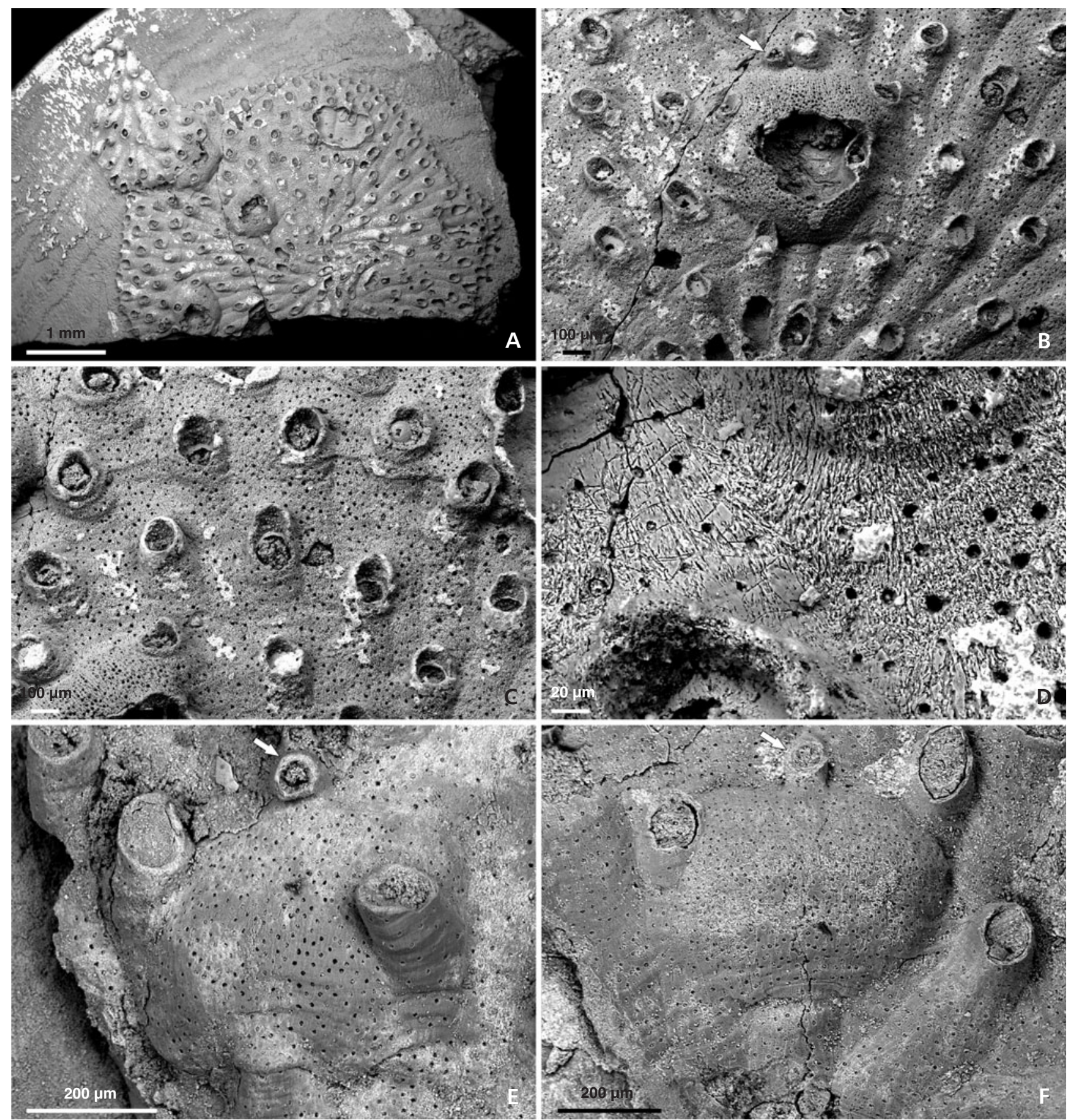

Figure 5. Microeciella calloviana sp. nov. from the Callovian hardground of the Zalas Quarry, southern Poland. • A - incomplete sheet-like colony with three gonozooids; B - gonozooid with a broken brood chamber and terminal ooeciopore (arrowed); C - autozooids; D - pseudopores; E, F - gonozooids with small terminal ooeciopores (arrowed). A-D - holotype (GIUS 8-3589-Z5/2), E, F - paratypes; E - GIUS 8-3589-M6; F - GIUS 8-3589-M7.

the rim of the peristome (Fig. 5C). Pseudopores circular to wide teardrop-shaped (Fig. 5D).

Gonozooids (Fig. 5B, E, F) common, occurring in two generations in the holotype (Fig. 5A). Proximal frontal wall indistinguishable from that of an autozooid. Brood chamber ovoidal in shape, inflated, varying from slightly longer than wide to wider than long even in the same col- ony; roof densely pseudoporous with edges indented by neighbouring autozooids. Ooeciopore terminal, semicircular, half the size of an autozooidal aperture, situated on a short, upright ooeciostome (Fig. 5B, E, F).

Remarks. - Gonozooid shape, ooeciopore size and location, as well as pseudopore characteristics, are similar in all 

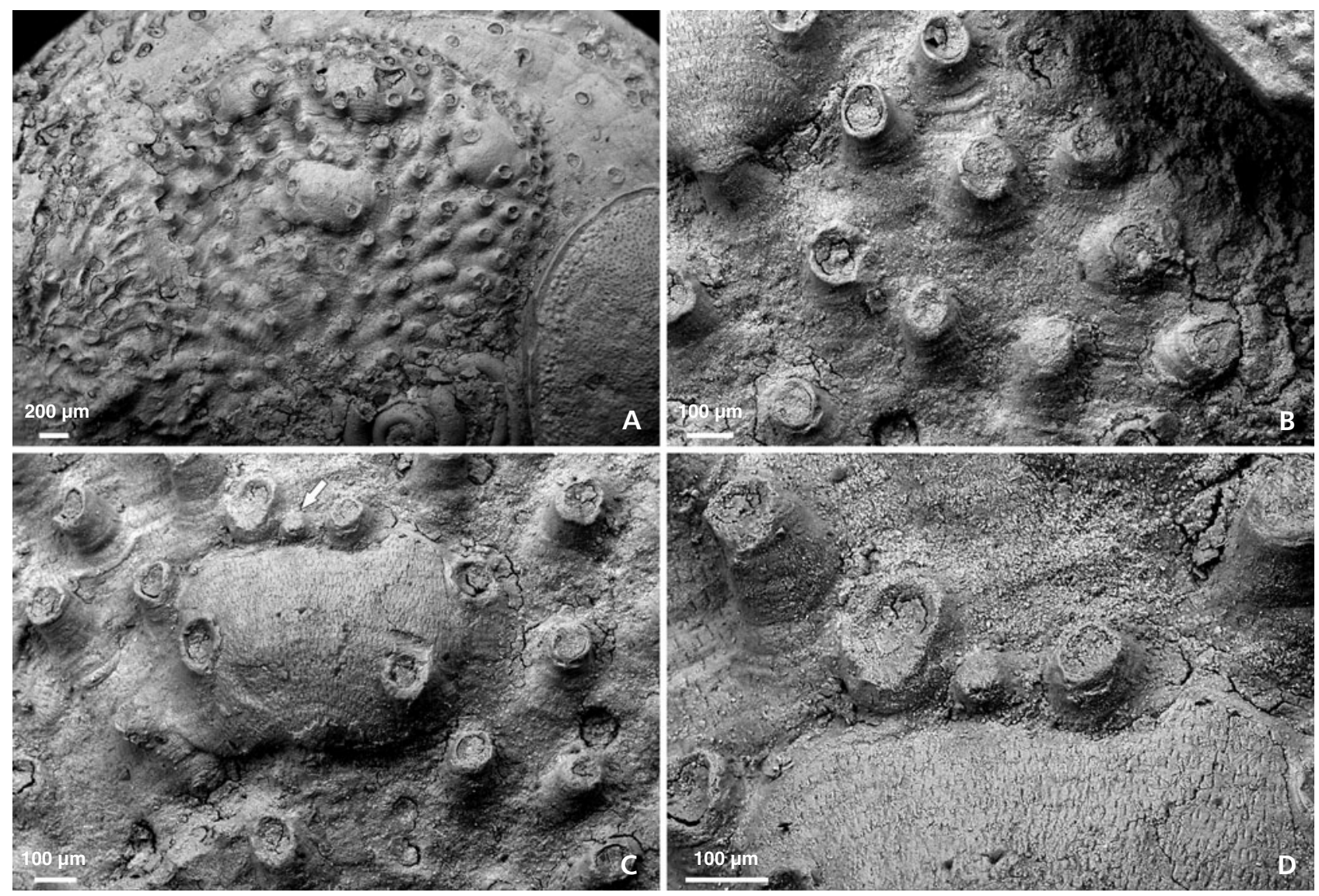

Figure 6. Microeciella aff. annae Zatoń \& Taylor, 2009 from the Callovian hardground of the Zalas Quarry, southern Poland, GIUS 8-3589-C/W-230/2. • A - sheet-like colony with four gonozooids; B - autozooids; C - gonozooid with terminal ooeciopore (arrowed); D - close-up of the tiny ooeciopore (centre), note the elongate, slit-like pseudopores on both the autozooidal and brood chamber frontal walls.

four colonies included in this species. Some variations in brood chamber shape (width/length ratio) are present, even in the same colony, but brood chamber size is similar in the colonies, as are autozooidal frontal wall and aperture sizes, although some of the autozooids are wider in one paratype (GIUS 8-3589-M7).

With respect to the general appearance of the gonozooids and the terminal position of the ooeciopore, this species is reminiscent of the Bathonian species Microeciella annae described by Zaton \& Taylor (2009) from the Polish Jura. However, the autozooids are distinctly smaller and pseudopores are narrowly teardrop-shaped and spindle-like in the latter species. Another similar Bathonian taxon, $M$. aff. annae, also differs in having smaller autozooids, ovoidal gonozooids that are longer than wide, and transversely elliptical pseudopores (see Zatoń \& Taylor 2010). The Zalas species shows some similarities with Microeciella maleckii from the Upper Bathonian of the Polish Jura (Zatoń \& Taylor 2009). However, apart from the slightly smaller apertures, the latter species also differs in the subterminal location of the ooeciopore and the more teardrop-shaped pseudopores. In general, species of Microeciella, including the type species M. beliensis, have subterminal ooeciopores (see Hara \& Taylor 2009; Taylor 2009; Taylor \& Sequeiros 1982; Taylor \& Wilson 1999; Zatoń \& Taylor 2009, 2010), whereas the ooeciopore is terminal in M. calloviana.

\section{Microeciella aff. annae Zatoń \& Taylor, 2009}

Figure 6A-D

Material. - One colony encrusting a bivalve shell, GIUS 8-3589-C/W-230/2.

Measurements. - Autozooid frontal wall length: 410-550 $\mu \mathrm{m}$; autozooid frontal wall width: $140-170 \mu \mathrm{m}$; longitudinal apertural diameter: 70-100 $\mu \mathrm{m}$; transverse apertural diameter: 75-90 $\mu \mathrm{m}$; gonozooid total length: $860-1120 \mu \mathrm{m}$; brood chamber length: 460-650 $\mu \mathrm{m}$; gonozooid width: 600-790 $\mu \mathrm{m}$; ooeciopore length: $50 \mu \mathrm{m}$; ooeciopore width: $50 \mu \mathrm{m}$; pseudopore length: $14-18 \mu \mathrm{m}$.

Description. - Colony encrusting, sheet-like, bereniciform, multiserial, unilamellar (Fig. 6A). Autozooids short 

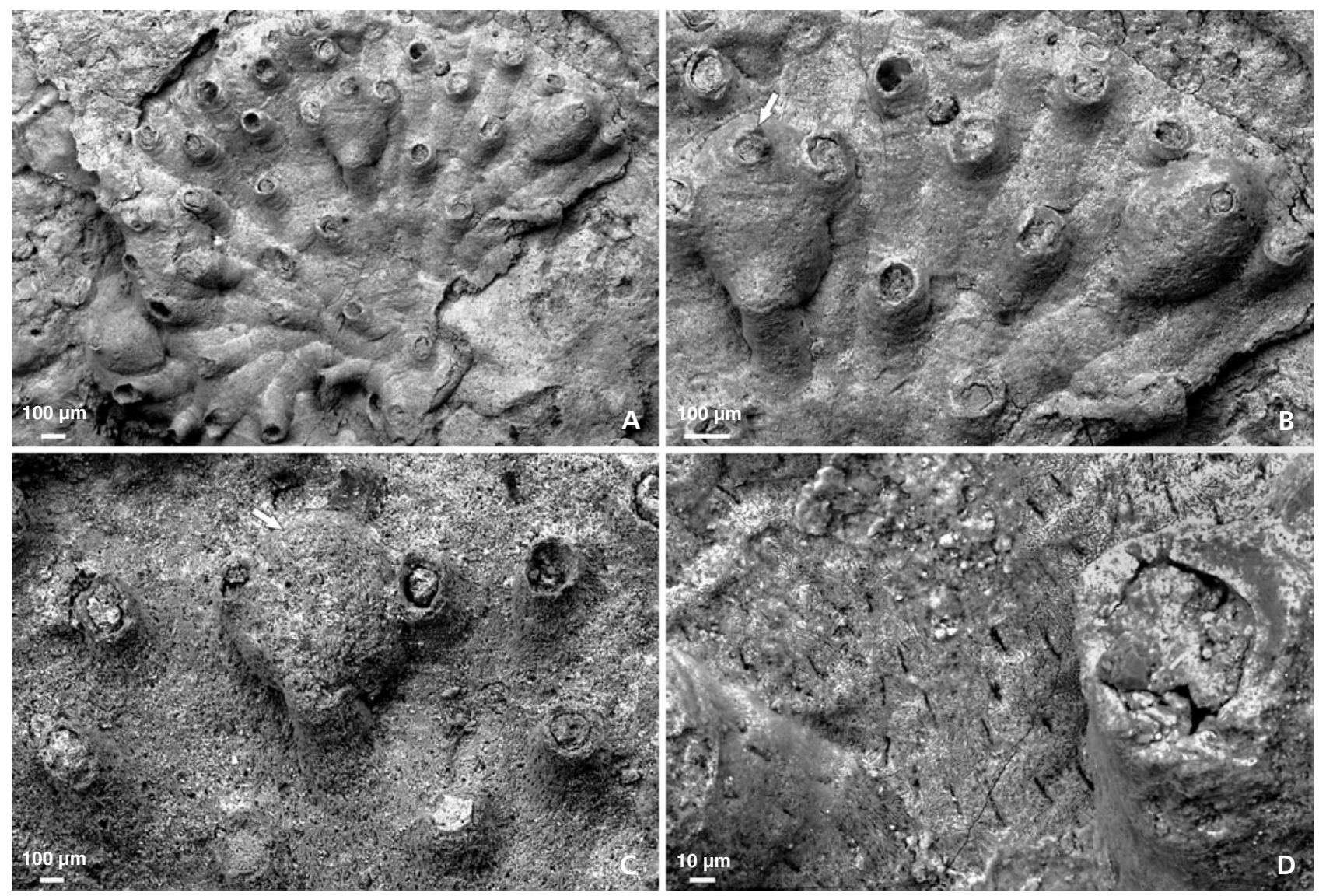

Figure 7. Microeciella cf. matisconensis Walter, 1970 from the Callovian hardground of the Zalas Quarry, southern Poland. • A - colony showing three gonozooids, close to the colony margin; B - autozooids associated with two gonozooids having subterminal ooeciopores (arrowed); C - another gonozooid with subterminal ooeciopore (arrowed); D - pseudopores. A, B, D - GIUS 8-3589-Z19/1, C - GIUS 8-3589-Z6.

with slightly convex frontal walls; zooidal boundaries shallow-grooved. Peristomes short, upright, tapering distally. Apertures circular to semicircular (Fig. 6B). Pseudopores dense, long, slit-like (Fig. 6D).

Gonozooids common, occurring in two generations, best developed at the colony margins (Fig. 6A). Proximal part indistinguishable from an autozooidal frontal wall. Brood chamber densely pseudoporous, inflated, ovoidal in shape, slightly wider than longer or equidimensional, with margins indented by neighbouring autozooids (Fig. 6C). Ooeciopore terminal, circular, smaller than an autozooid aperture, situated on a short, upright ooeciostome (Fig. 6D).

Remarks. - With respect to autozooid length and gonozooid shape, this taxon is most similar to Microeciella annae from the Bathonian of the Polish Jura (Zaton \& Taylor 2009). The latter species, however, is characterised by slightly smaller apertures, an ooeciopore twice the size of the present species, and more teardrop to spindle-like pseudopores. From another similar Lower Bathonian form, assigned to $M$. aff. annae by Zatoń \& Taylor (2010), the Zalas taxon differs in its larger gonozooids and slit-like pseudopores. Gonozooid shape and pseudopore characteristics are similar to Microeciella sp. from the Upper Bathonian-Lower Callovian of Balin (see Taylor 2009), although the ooeciopore is subterminal in the Balin species.

\section{Microeciella cf. matisconensis (Walter, 1970) Figure 7A-D}

Material. - Four colonies encrusting bivalve shells: GIUS 8-3589-Z5/2, GIUS 8-3589-Z6, GIUS 8-3589-Z19/1, GIUS 8-3589-M12/2.

Measurements. - Autozooid frontal wall length: 470-800 $\mu \mathrm{m}$; autozooid frontal wall width: 100-170 $\mu \mathrm{m}$; longitudinal apertural diameter: 70-100 $\mu \mathrm{m}$; transverse apertural diameter: 60-90 $\mu \mathrm{m}$; gonozooid total length: $720-970 \mu \mathrm{m}$; brood chamber length: $320-470 \mu \mathrm{m}$; gonozooid width: 290-430 $\mu \mathrm{m}$; ooeciopore length: $50 \mu \mathrm{m}$; ooeciopore width: $50 \mu \mathrm{m}$; pseudopore length: $12-15 \mu \mathrm{m}$. 

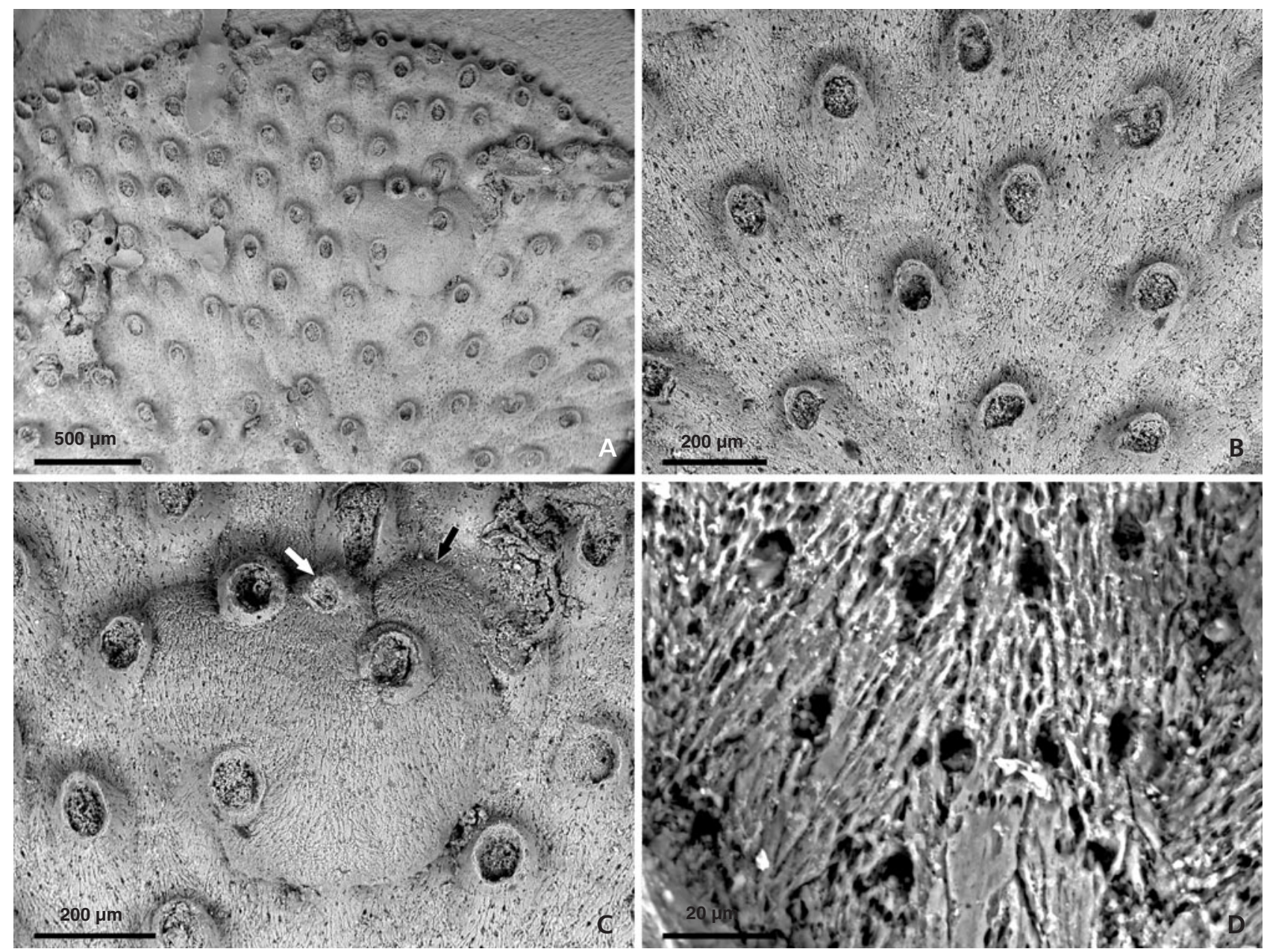

Figure 8. Microeciella cf. maleckii Zatoń \& Taylor, 2009 from the Callovian hardground of the Zalas Quarry, southern Poland, GIUS 8-3589-M8. - A - part of a sheet-like colony; B - autozooids; C - gonozooid with subterminal ooeciopore (white arrow), note the neighbouring autozooid embraced by the brood chamber (black arrow); D - pseudopores.

Description. - Colony encrusting, sheet-like, bereniciform, multiserial, unilamellar (Fig. 7A). Autozooids long, with slightly convex frontal walls; zooidal boundaries variably distinct, shallowly grooved. Peristomes short, tapering distally. Apertures circular to slightly longitudinally elongate (Fig. 7B). Pseudopores long, slit-like (7D).

Gonozooids common, occurring in up to two generations (Fig. 7A). Proximal frontal wall indistinguishable from that of an autozooid. Brood chambers small, inflated, globular in shape, slightly longer than wide; edges indented by neighbouring autozooids. Ooeciopore circular in outline, subterminal, smaller than an autozooid aperture (Fig. 7B, C).

Remarks. - Autozooid width and gonozooidal characteristics in the Zalas material are identical to those of the French species Microeciella matisconensis (Walter, 1970). However, pseudopore morphology is unknown in
M. matisconensis, making direct comparison difficult and leaving some doubt about the conspecificity of the French and Polish material. The Microeciella sp. of Taylor (2009) from the Upper Bathonian-Lower Callovian of Balin, southern Poland, is similar with respect to the subterminal position of the ooeciopore and slit-like pseudopores; however, the brood chambers are larger and wider, and the ooeciopore transversely elongated in this species. The Zalas form is similar to other Jurassic species of Microeciella in the subterminal position of the ooeciopore but differs in having characteristically small, globular brood chambers.

Microeciella cf. maleckii Zatoń \& Taylor, 2009

Figure 8A-D

Material. - One colony encrusting bivalve shell, GIUS 8-3589-M8. 
Measurements. - Autozooid frontal wall length: 380-400 $\mu \mathrm{m}$; autozooid frontal wall width: 100-120 $\mu \mathrm{m}$; longitudinal apertural diameter: 70-90 $\mu \mathrm{m}$; transverse apertural diameter: 50-60 $\mu \mathrm{m}$; gonozooid total length: $620 \mu \mathrm{m}$; brood chamber length: $600 \mu \mathrm{m}$; gonozooid width: $550 \mu \mathrm{m}$; ooeciopore length: $50-60 \mu \mathrm{m}$; ooeciopore width: $40 \mu \mathrm{m}$; pseudopore length: $8-10 \mu \mathrm{m}$; pseudopore width: $6-7 \mu \mathrm{m}$.

Description. - Colony encrusting, sheet-like, bereniciform, multiserial, unilamellar (Fig. 8A). Autozooids elongate with slightly convex frontal walls; zooidal boundaries distinct distally, shallowly grooved. Peristomes short, tapering distally. Apertures semicircular to oval (Fig. 8B). Pseudopores teardrop-shaped to oval in outline (Fig. 8D).

Gonozooids infrequent, the preserved example having a proximal frontal wall indistinguishable from an autozooid frontal wall. Brood chamber ovoidal, with convex frontal wall, widening distally, its margin indented by neighbouring autozooids; right distal end embracing one of the autozooidal peristomes and then rejoining the rest of the brood chamber close to the ooeciopore (Fig. 8C). Ooeciopore circular, smaller than an autozooid aperture, situated on a short, subterminal ooeciostome.

Remarks. - The ovoidal, distally widening brood chamber with subterminal ooeciopore and marginal indentation by the neighbouring autozooids invite comparison between this form and the Upper Bathonian species M. maleckii Zaton \& Taylor, 2009. However, the complete envelopment of an autozooidal peristome by the brood chamber evident in the colony from Zalas is unknown in M. maleckii and other Jurassic species of Microeciella. With respect to other morphological features of the autozooids, brood chamber and pseudopores, the two species are similar to each other, M. maleckii differing from the Zalas form only in the slightly longer autozooidal frontal walls.

Family Multisparsidae Bassler, 1935

Genus Reptomultisparsa d'Orbigny, 1853

Type species. - Diastopora incrustans d'Orbigny, 1850 (Taylor 1984).

\section{Reptomultisparsa viskovae sp. nov.} Figure 9A-D

Types. - Holotype: GIUS 8-3589-Z5/1 (Fig. 9A-D).

Type locality. - Zalas Quarry, southern Poland.
Type horizon. - Callovian hardground, Middle Jurassic.

Etymology. - In honor of Lena A. Viskova (PIN, Moscow), in recognition of her extensive contributions to the study of post-Palaeozoic bryozoans.

Material. - One colony encrusting a bivalve shell, GIUS 8-3589-Z5/1 (holotype).

Measurements. - Autozooid frontal wall length: 530-600 $\mu \mathrm{m}$; autozooid frontal wall width: 110-140 $\mu \mathrm{m}$; longitudinal apertural diameter: $60-90 \mu \mathrm{m}$; transverse apertural diameter: 60-90 $\mu \mathrm{m}$; gonozooid total length: $1040 \mu \mathrm{m}$; brood chamber length: $640 \mu \mathrm{m}$; gonozooid width: $390 \mu \mathrm{m}$; ooeciopore length: $70 \mu \mathrm{m}$; ooeciopore width: $90 \mu \mathrm{m}$; pseudopore length: $8-10 \mu \mathrm{m}$; pseudopore width: $12-15 \mu \mathrm{m}$; ancestrula length: $190 \mu \mathrm{m}$; protoecium length: $140 \mu \mathrm{m}$; protoecium width: $130 \mu \mathrm{m}$.

Diagnosis. - Reptomultisparsa species having elongate autozooids, spindle-shaped brood chamber with subterminal ooeciopore, and transversely elliptical pseudopores partly closed by sunken walls at their proximal and distal ends leaving a transverse, slit-like opening.

Description. - Colony encrusting, fan-shaped, multiserial, unilamellar, small (Fig. 9A). Ancestrula with circular, convex, smooth protoecium; distal tube straight, short; one distal autozooid budded from ancestrula.

Autozooids elongate with slightly convex frontal walls; zooidal boundaries well marked by shallow grooves (Fig. 9B, C). Peristomes short, tapering distally. Apertures semicircular to circular (Fig. 9C). Pseudopores transversely elliptical, partly closed by sunken walls at their proximal and distal ends leaving a transverse, slit-like opening (Fig. 9D).

Only one gonozooid preserved (Fig. 9A, B); its proximal frontal wall long, convex, indistinguishable from an autozooidal frontal wall. Brood chamber longer than wide, spindle-shaped, convex, with edges indented by apertures of neighbouring autozooids at mid-length. Roof densely pseudoporous. Ooeciopore subterminal, semi-circular, smaller than an autozooidal aperture, situated on a short, upright ooeciostome (Fig. 9C).

Remarks. - From other representatives of the genus Reptomultisparsa, this new species differs in its transversely elliptical pseudopores partly closed by sunken walls along their proximal and distal sides. Although the material consists of only one colony, these unusual pseudopores allow the new species to be established. Partial occlusion of pseudopores by ring-like walls or spines has been described previously in cyclostome bryozoans (e.g., Weedon \& Taylor 1997) but the mode of closure in $R$. viskovae appears to be unique. 

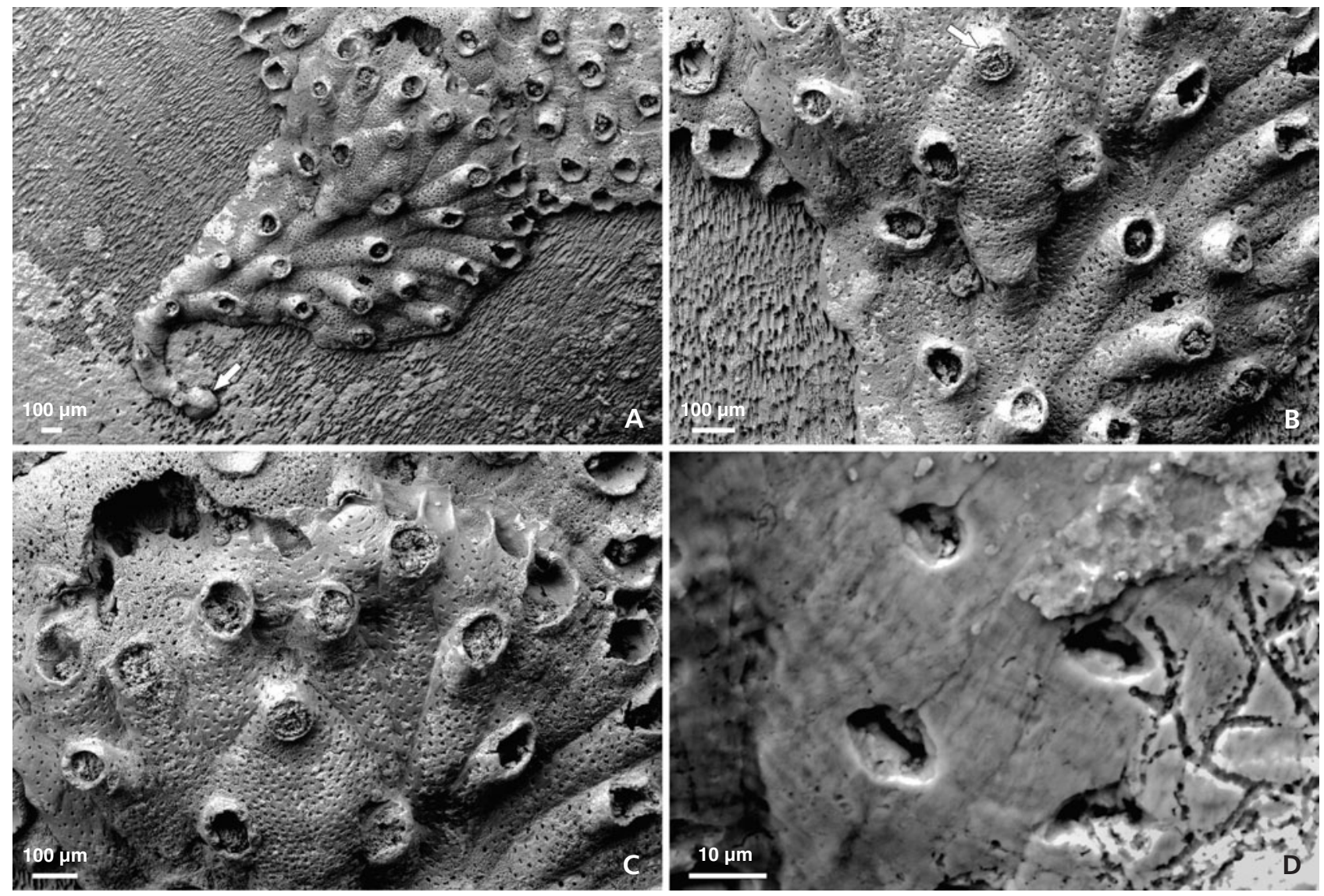

Figure 9. Reptomultisparsa viskovae sp. nov. from the Callovian hardground of the Zalas Quarry, southern Poland, GIUS 8-3589-Z5/1. • A - small colony overgrowing another cyclostome, with ancestrula (arrowed); B - autozooids and gonozooid having subterminal ooeciopore (arrowed); C - close-up of the colony growing edge; $\mathrm{D}$ - pseudopores, note microendoliths in lower right.

Reptomultisparsa aff. kawodrzanensis Zatoń \& Taylor, 2010

Figure 10A-D

Material. - One colony encrusting a bivalve shell, GIUS 8-3589-Z2.

Measurements. - Autozooid frontal wall length: 420-800 $\mu$ m; autozooid frontal wall width: $125-175 \mu \mathrm{m}$; longitudinal apertural diameter: $110-140 \mu \mathrm{m}$; transverse apertural diameter: 87-120 $\mu \mathrm{m}$; gonozooid total length: $1280-1450 \mu \mathrm{m}$; brood chamber length: $720-1100 \mu \mathrm{m}$; gonozooid width: 320 to $420 \mu \mathrm{m}$; ooeciopore length: $90 \mu \mathrm{m}$; ooeciopore width: $110 \mu \mathrm{m}$; pseudopore length: $6-8 \mu \mathrm{m}$; pseudopore width: $6-8 \mu \mathrm{m}$.

Description. - Colony encrusting, sheet-like, bereniciform, multiserial, unilamellar (Fig. 10A). Autozooids elongate with convex frontal walls; zooidal boundaries well marked with shallow grooves. Peristomes short, tapering distally. Apertures semicircular to longitudinally elongated (Fig. 10B). Pseudopores circular to teardrop-shaped, unclear due to the worn colony surface (Fig. 10D).
Gonozooids common, with proximal frontal wall similar in width to an autozooid frontal wall. Brood chamber longitudinally elongated, much longer than wide, ovoidal in shape; edges indented by neighbouring autozooids. Ooeciopore subterminal, subcircular, slightly wider than longer, smaller than an autozooidal aperture (Fig. 10C).

Remarks. - With respect to autozooid shape and size, gonozooid morphology and pseudopore characteristics, the form described here is most similar to Reptomultisparsa kawodrzanensis Zaton \& Taylor, 2010 from the Lower Bathonian of the Polish Jura. It differs, however, in having a generally shorter brood chamber (720-110 $\mu \mathrm{m}$ vs. 940-1720 $\mu \mathrm{m}$ ) and lacking a distinct ooeciostome, although the latter may be a preservational artefact. Another species, Reptomultisparsa harae Zatoń \& Taylor, 2009 from the Upper Bajocian and Middle Bathonian of England and Poland, has a similar gonozooid but differs in its long, slit-like pseudopores. Despite these differences from existing species of Reptomultisparsa, more material is needed to warrant the establishment of a new species. 

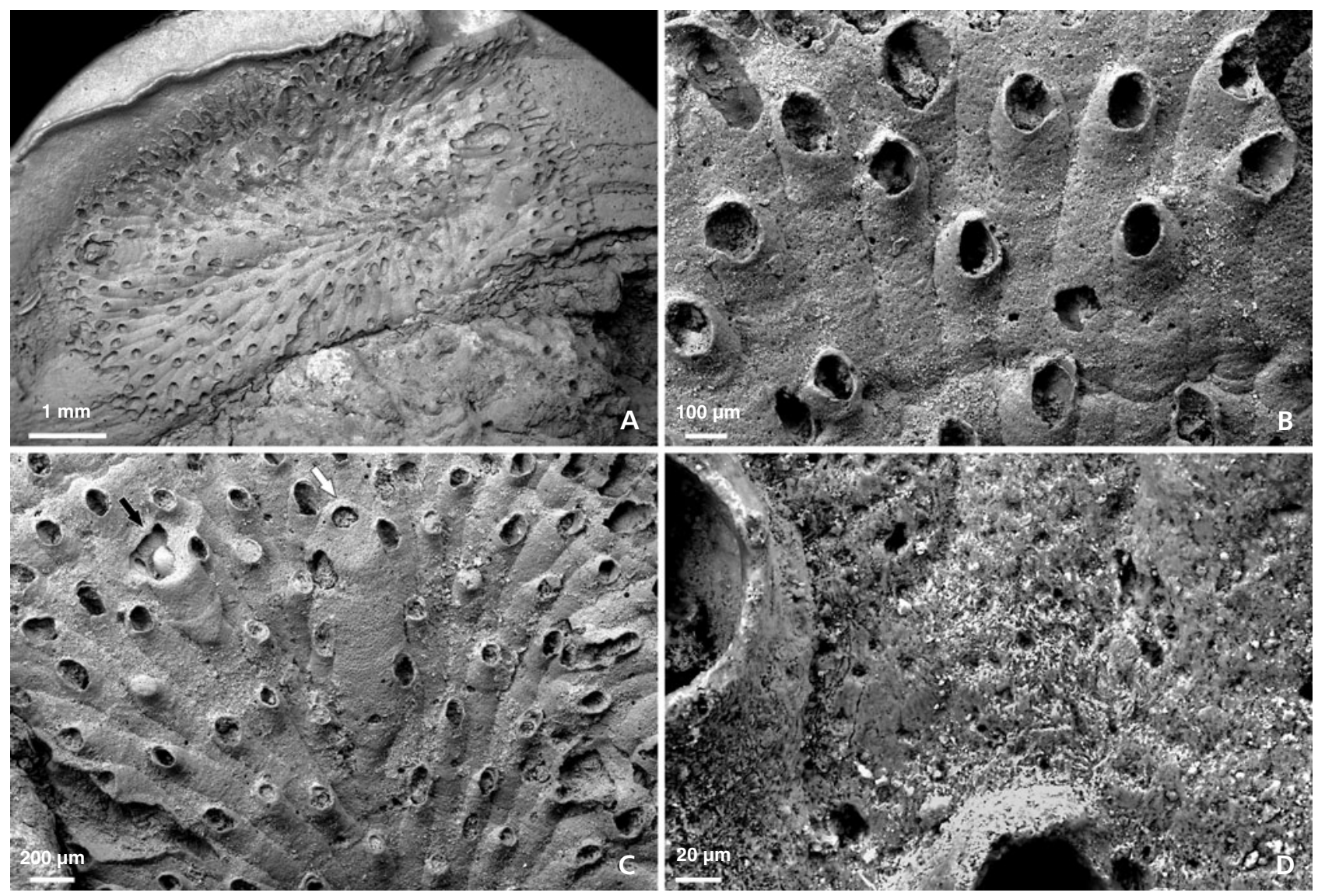

Figure 10. Reptomultisparsa aff. kawodrzanensis Zaton \& Taylor, 2010 from the Callovian hardground of the Zalas Quarry, southern Poland, GIUS 8-3589-Z2. A - fertile, sheet-like colony; B - autozooids; C - complete gonozooid with subterminal ooeciopore (white arrow) and an aborted gonozooid (black arrow); D - pseudopores.

\section{Reptomultisparsa sp.}

Figure 11A-D

Material. - Two colonies encrusting bivalve shells: GIUS 8-3589-M5/3 and GIUS 8-3589-C/W-230/1, the first one being fertile.

Measurements. - Autozooid frontal wall length: 290-710 $\mu$; autozooid frontal wall width: 140-190 $\mu \mathrm{m}$; longitudinal apertural diameter: $70-130 \mu \mathrm{m}$; transverse apertural diameter: 90-110 $\mu \mathrm{m}$; brood chamber length: $760 \mu \mathrm{m}$; gonozooid width: $650 \mu \mathrm{m}$; ooeciopore length: $65 \mu \mathrm{m}$; ooeciopore width: $90 \mu \mathrm{m}$; pseudopore length: $4 \mu \mathrm{m}$; pseudopore width: $4 \mu \mathrm{m}$.

Description. - Colony encrusting, muliserial, unilamellar, bereniciform. Autozooids short, with flat frontal walls; zooidal boundaries indistinct (Fig. 11A, B). Peristomes short, tapering distally. Apertures circular (Fig. 11B). Pseudopores dense, tiny, semicircular to slightly ovoidal in outline (Fig. 11D).

Gonozooid with broad oval, inflated brood chamber, its edges indented by apertures of neighbouring autozooids for three-quarters of the length (Fig. 11C). Ooeciopore subterminal, semicircular, slightly wider than longer, similar to an autozoidal aperture in width, situated on a very short, upright ooeciostome.

Remarks. - This taxon is most similar to the Reptomultisparsa sp. of Hara \& Taylor (2009) from the Lower Kimmeridgian of Wierzbica and Małogoszcz in the Holy Cross Mountains, Poland. The latter, however, has a wider and flatter brood chamber crossed by transverse growth bands. It is also reminiscent of Reptomultisparsa tumida Taylor, 1980 from the Upper Bathonian of England but this slightly older species has a more oval brood chamber.

Family Plagioeciidae Canu, 1918

\section{Genus Hyporosopora Canu \& Bassler, 1929}

Type species. - Hyporosopora typica Canu \& Bassler, 1929, by original designation. 

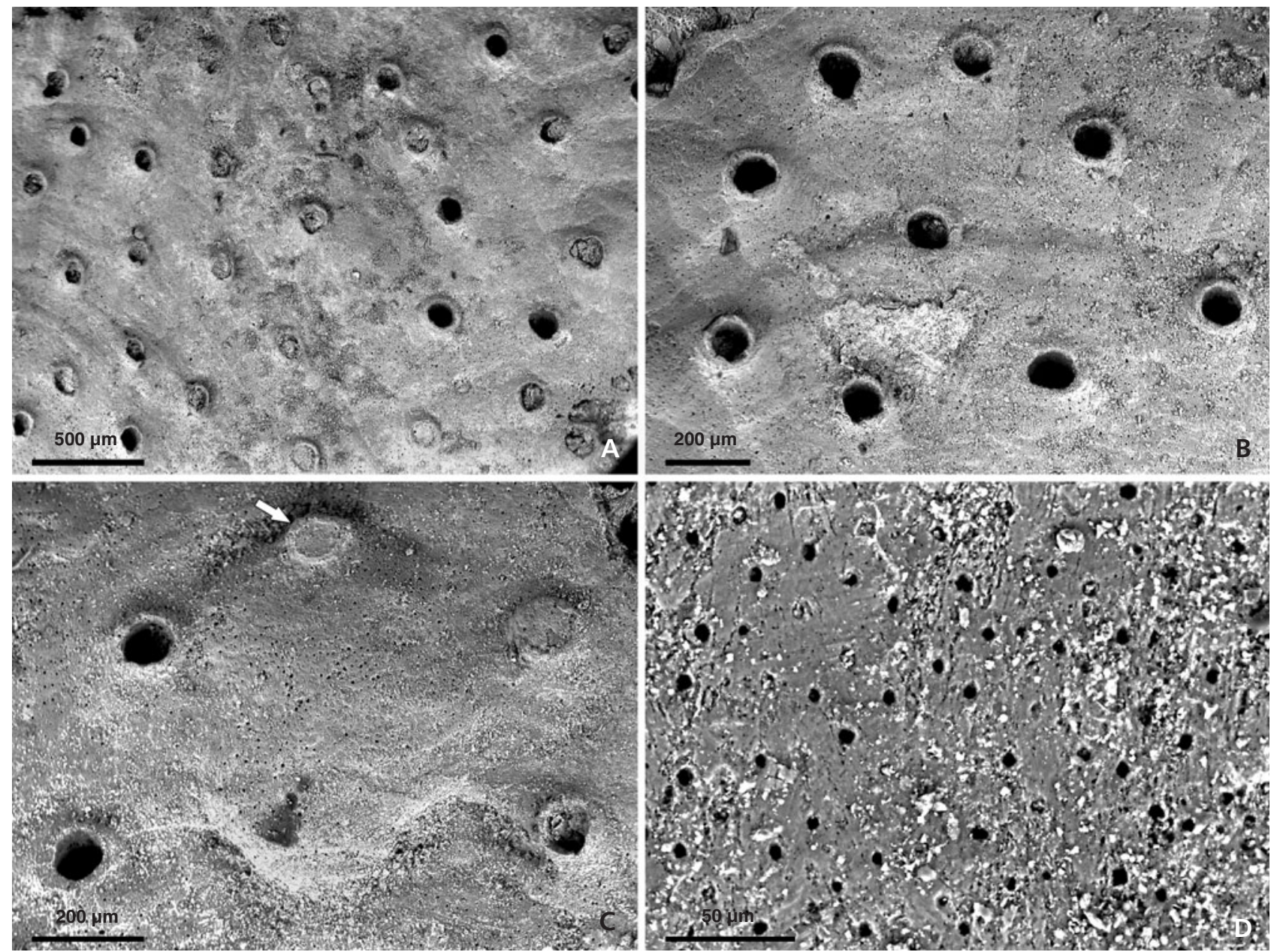

Figure 11. Reptomultisparsa sp. from the Callovian hardground of the Zalas Quarry, southern Poland, GIUS 8-3589-M5/3. • A - nearly flat colony surface; B - autozooids; C - gonozooid with subterminal ooeciopore (arrowed); D - pseudopores.

\section{Hyporosopora tenera (Reuss, 1867)}

Figure $12 \mathrm{~A}-\mathrm{F}$

1867 Berenicea tenera, Reuss, p. 8 (partim), pl. 1, fig. 9.

2009 Hyporosopora tenera (Reuss). - Taylor, p. 37, figs 7C, 9A-F.

2009 Hyporosopora tenera (Reuss). - Zatoń \& Taylor, p. 282 , fig. 12 .

Material. - Nine colonies encrusting bivalve shells, seven of which were SEMed: GIUS 8-3589-M12/1, GIUS 8-3589-M10, GIUS 8-3589-M2, GIUS 8-3589-230-7, GIUS 8-3589-Z3/8, GIUS 8-3589-Z6a, GIUS-3589-Z1.

Measurements. - Autozooid frontal wall length: 230-430 $\mu$; autozooid frontal wall width: 90-130 $\mu \mathrm{m}$; longitudinal apertural diameter: $60-100 \mu \mathrm{m}$; transverse apertural diameter: 60-80 $\mu \mathrm{m}$; gonozooid total length: 570-1100 $\mu \mathrm{m}$; brood chamber length: $600 \mu \mathrm{m}$; gonozooid width: 450-600 $\mu \mathrm{m}$; ooeciopore length: 50-60 $\mu \mathrm{m}$; ooeciopore width: $60-80 \mu \mathrm{m}$; pseudopore length: 9-17 $\mu \mathrm{m}$; pseudopore width: $2-3 \mu \mathrm{m}$.

Description. - Colony encrusting, multiserial, bereniciform, unilamellar, usually a small disc up to $3200 \mu \mathrm{m}$ in diameter, often elliptical with a maximum width of $6400 \mu \mathrm{m}$, but also may form small flabelliform colonies; growing edge thin, composed of one generation of zooids (Fig. 12A).

Autozooids small, longitudinally elongate, frontal walls convex, with distinct boundaries, covered by transverse ridges spaced irregularly about 18-25 $\mu \mathrm{m}$ apart, in some places discontinuous, low in profile, present over brood chambers. Apertures oval in shape, sometimes nearly circular, arranged roughly in quincunx, more crowded at the colony margin; terminal diaphragms present but rare, located a little beneath the frontal wall, most of the apertures sealed by the sediment. Peristomes very narrow, tapering distally in the central part of the colony (Fig. 12B). Pseudopores slit-like, rather long, in some 

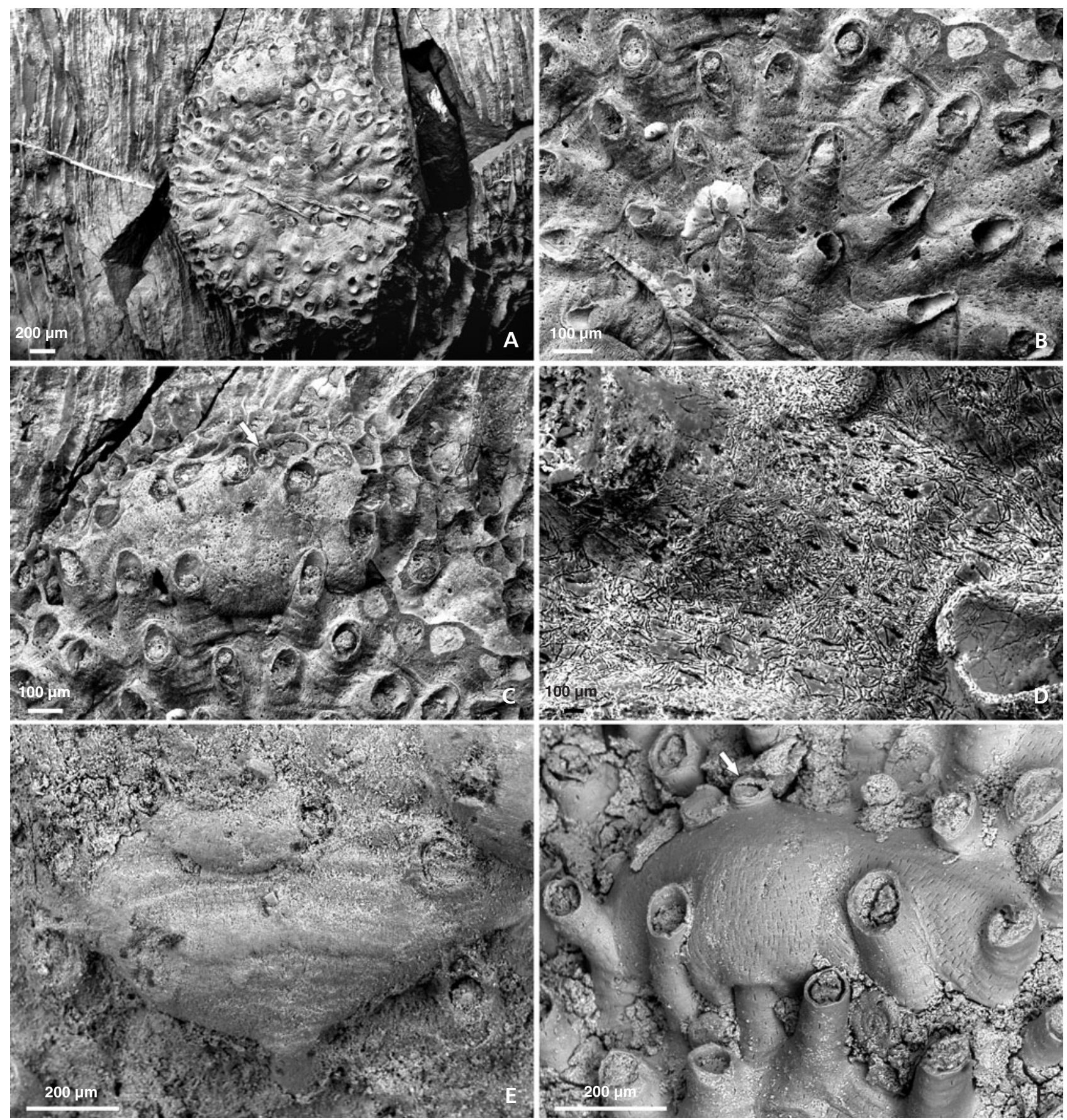

Figure 12. Hyporosopora tenera (Reuss, 1867) from the Callovian hardground of the Zalas Quarry, southern Poland. • A - disc-shaped colony view; B - autozooids; C - gonozooid with subterminal ooeciopore (arrowed); D - pseudopores; E, F - gonozooids from two colonies with subterminal ooeciopore well-visible in F (arrowed). A-D - GIUS 8-3589-Z3/8; E - GIUS 8-3589-230-7; F - GIUS 8-3589-M12/1.

cases dagger-shaped, covering the entire colony surface (Fig. 12D).

Gonozooids transversely elongate in outline, almost half longer than wide, usually one to few gonozooids present close to the colony margin, distal edge often straight, margins surrounded densely by the autozooidal apertures. Brood chamber inflated, roughly globular, wider than long
(Fig. 12C, E, F). Ooeciopore terminal, transversely elliptical, smaller that an autozooidal aperture (Fig. 12F).

Remarks. - This Zalas bryozoan agrees in almost all morphological and morphometrical features well with the type material of $H$. tenera from the Upper Bathonian-Early Callovian of Balin recently revised by Taylor (2009). The main 

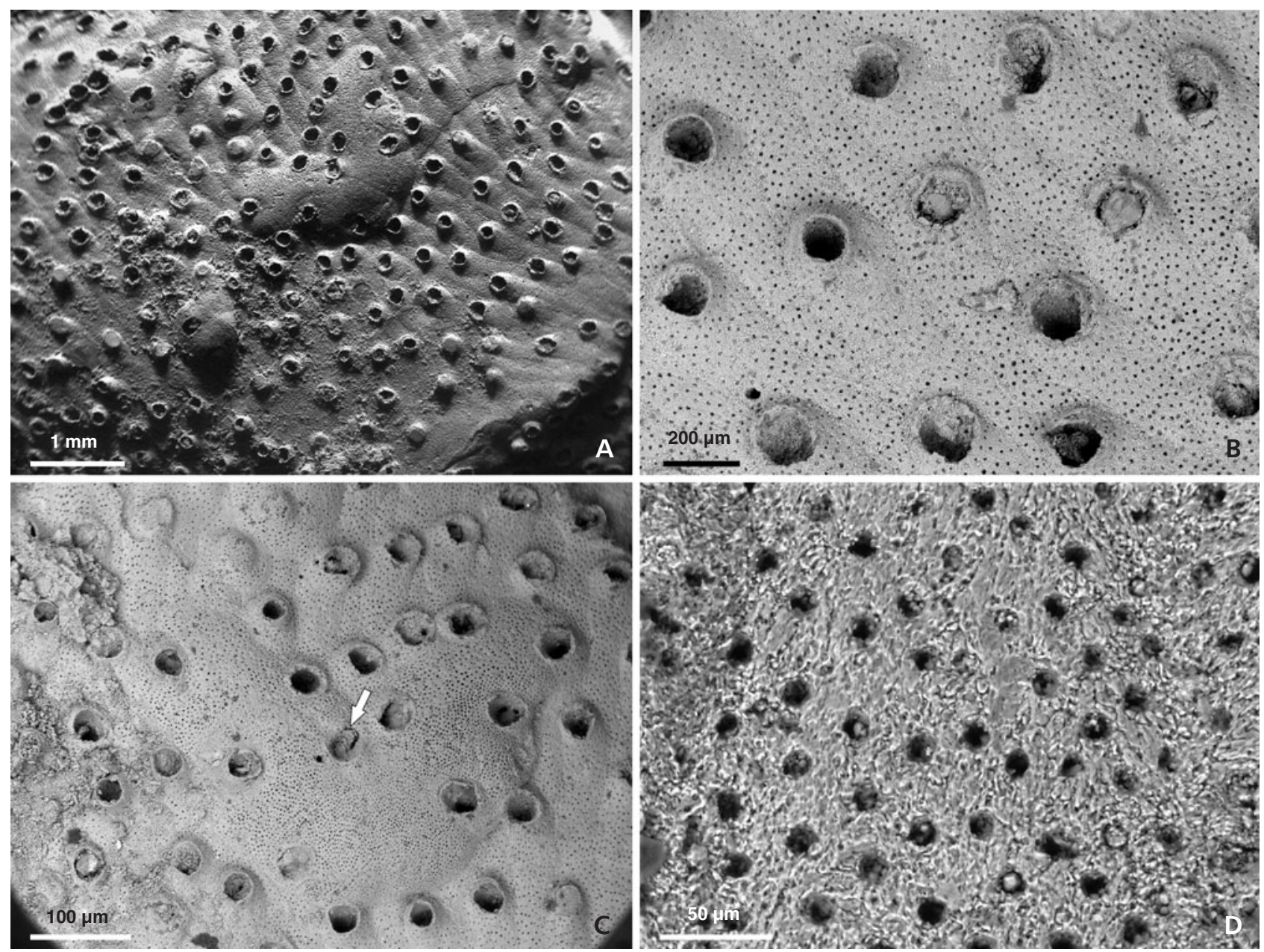

Figure 13. Hyporosopora aff. sauvagei (Gregory, 1896) from the Callovian hardground of the Zalas Quarry, southern Poland, GIUS 8-3589-M13. - A - part of a large colony imaged in SE mode; B - autozooids; C - gonozooid with subterminal ooeciopore (arrowed); D - round-shaped pseudopores.

differences are the shorter autozooecial frontal walls and brood chambers in the Zalas material. Diaphragms, which are common in the Balin Oolite material, are less frequent in the Zalas specimens, and fine growth lines on the colony surface are better defined in specimens from Balin.

Recently described material from the Middle Jurassic ore-bearing clays of the Polish Jura resembles the specimens from Zalas but the gonozooids are larger (see Zaton \& Taylor 2009, p. 282, fig. 12C). The majority of colonies of $H$. tenera from Zalas are subcircular in outline but others are flabellate. The characteristic longitudinally elongate, narrow, slit-like pseudopores that densely cover the surface are obscured by encrustations of ferrous oxide in some of the specimens.

\section{Hyporosopora aff. sauvagei (Gregory, 1896)} Figure 13A-D

Material. - One, large incomplete colony encrusting a belemnite guard, GIUS 8-3589-M13.
Measurements. - Autozooid frontal wall length: 580-770 $\mu \mathrm{m}$; autozooid frontal wall width: 260-290 $\mu \mathrm{m}$; longitudinal apertural diameter: $140-170 \mu \mathrm{m}$; transverse apertural diameter: $120-150 \mu \mathrm{m}$; gonozooid total length: $2400 \mu \mathrm{m}$; brood chamber length: $2100 \mu \mathrm{m}$; gonozooid width: $1500 \mu \mathrm{m}$; ooeciopore length: 120-130 $\mu \mathrm{m}$; ooeciopore width: $110 \mu \mathrm{m}$; pseudopore length: 10-13 $\mu \mathrm{m}$; pseudopore width: 10-11 $\mu \mathrm{m}$.

Description. - Colony large (more than $20 \mathrm{~mm}$ in diameter when complete), encrusting, sheet-like, bereniciform, unilamellar (Fig. 13A).

Autozooids large, gently convex and slightly sinuous, expanded a little below the apertures with well-defined boundaries (Fig. 13B). Peristomes short and narrow, slightly tapering distally. Apertures circular to elliptical, some closed by terminal diaphragms (Fig. 13A). Pseudopores very distinctive, wide teardrop-shaped to circular, densely and regularly spaced (Fig. 13D).

Gonozooids large, brood chamber much broader than long, boomerang-shaped with two prominent and 

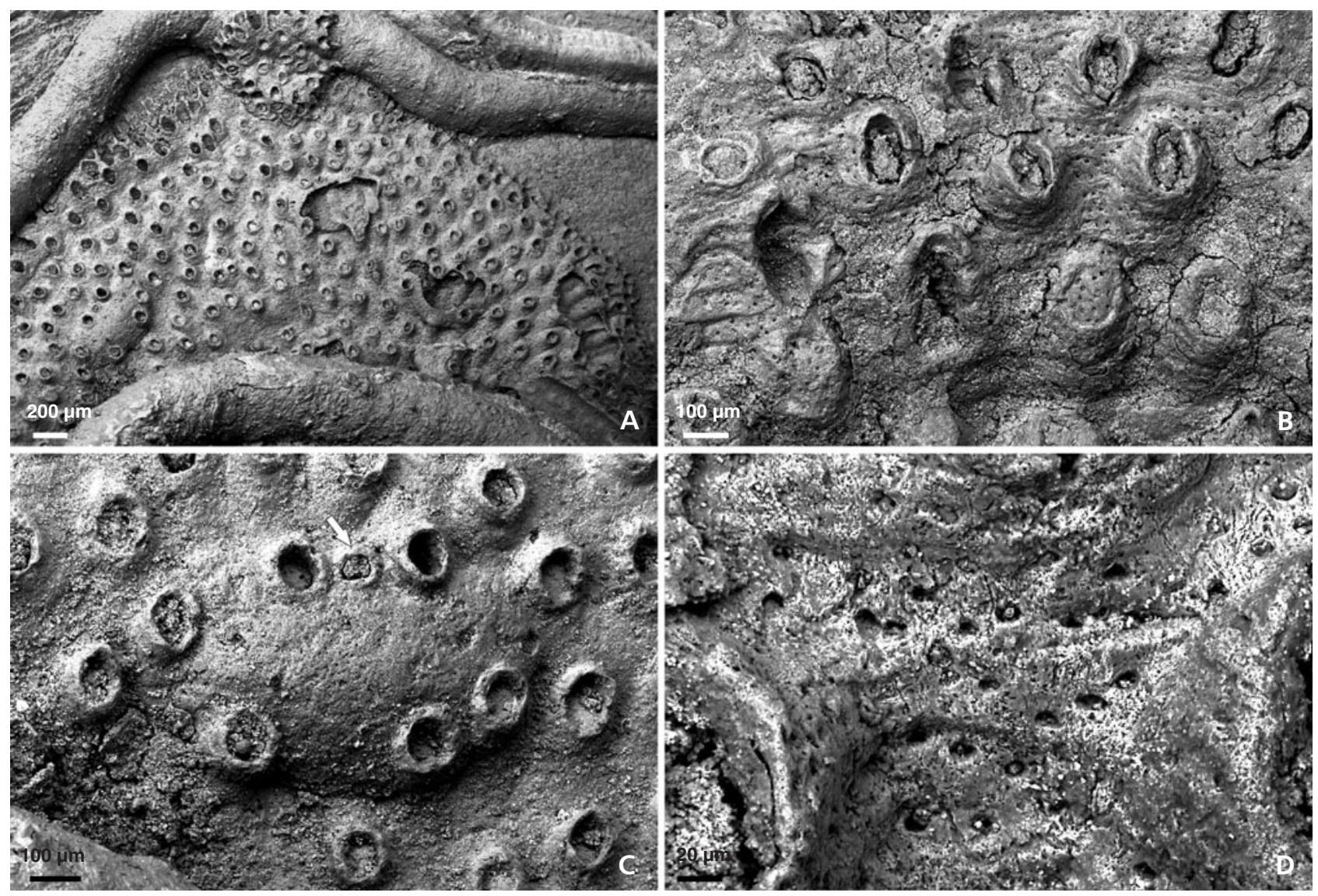

Figure 14. Hyporosopora $\mathrm{cf}$. enstonensis Pitt \& Thomas, 1969 from the Callovian hardground of the Zalas Quarry, southern Poland. • A - growing margin of the fertile colony associated with serpulid tubes; B - autozooids; C - gonozooid with subterminal ooeciopore (arrowed); D - pseudopores. A, C - GIUS 8-3589-Z11; B, D - GIUS 8-3589-Z3.

symmetrically arranged distal lobes (Fig. 13A, C). Brood chamber roof indented at its edges by numerous autozooidal apertures. Ooeciopore terminal, subcircular, slightly longer then wide, a little smaller than an autozooidal aperture, encircled by a narrow, short ooeciostome.

Remarks. - The holotype of Hyporosopora sauvagei (NHM B194) was described by Gregory (1896, p. 82, pl. 3, fig. 4) from the Upper Bathonian Bradford Clay of Bradford-on-Avon, Wiltshire, England. In the overall morphology of the colony, autozooids and gonozooids, Gregory's species resembles the Callovian specimen from Zalas. However, pseudopores are wide teardrop-shaped to circular in Polish material identified as Hyporosopora aff. sauvagei (Taylor 2009, Zatoń \& Taylor 2009), as well as in the Zalas material studied here, whereas they are crescent-shaped in the holotype of $H$. sauvagei (see Hara \& Taylor 2009). In view of the emerging importance of pseudopore morphology in cyclostome taxonomy, this difference should be regarded as significant at species level.

The distinctive boomerang-shaped gonozooid in the Zalas specimen studied here also recalls some other Juras- sic species of Hyporosopora, such as Hyporosopora sp. of Taylor (1981) from the Tithonian Portland Stone of Dorset, and H. radomensis Hara \& Taylor, 2009 from the Lower Kimmeridgian of the Holy Cross Mountains, Poland. The latter differs from the Zalas species in having narrower autozooidal frontal wall widths as well as a smaller ooeciopore.

Hyporosopora cf. enstonensis Pitt \& Thomas, 1969 Figure 14A-D

Material. - Two colonies encrusting bivalve shells: GIUS 8-3589-Z3/11, GIUS 8-3589-Z11/2.

Measurements. - Autozooid frontal wall length: 300-430 $\mu \mathrm{m}$; autozooid frontal wall width: 140-180 $\mu \mathrm{m}$; longitudinal apertural diameter: 100-130 $\mu \mathrm{m}$; transverse apertural diameter: 70-80 $\mu \mathrm{m}$; gonozooid total length: 750-900 $\mu \mathrm{m}$; brood chamber length: $600 \mu \mathrm{m}$; gonozooid width: 500-660 $\mu \mathrm{m}$; ooeciopore length: $40-50 \mu \mathrm{m}$; ooeciopore width: $50 \mu \mathrm{m}$; pseudopore length: 5-7 $\mu \mathrm{m}$; pseudopore width: 7-12 $\mu \mathrm{m}$. 

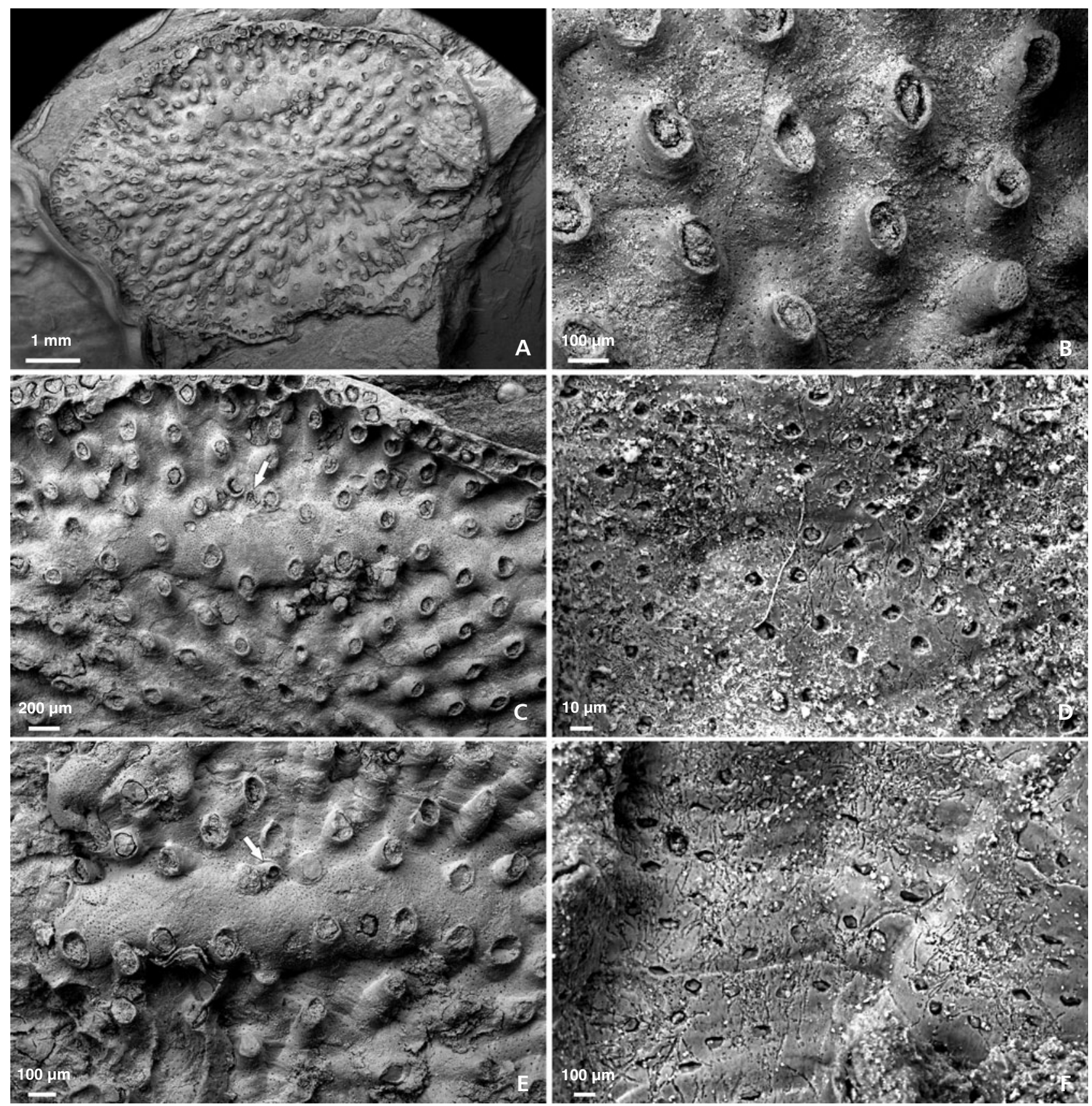

Figure 15. Mesonopora walteri sp. nov. (A-D) and Mesonopora aff. walteri sp. nov. (E, F) from the Callovian hardground of the Zalas Quarry, southern Poland. - A - general view of the sheet-like colony; B - autozooids; C, E - transversely elongate gonozooids with terminal ooeciopores (arrows); D, F - pseudopores. A-D - holotype, GIUS 8-3589-Z10/2; E, F - GIUS 8-3589-Z9/3.

Description. - Colony encrusting, irregularly discoidal, unilamellar to multilamellar, rather thin, 5.5 to $7 \mathrm{~mm}$ in diameter. One small subcolony, which partly overgrows the parent colony, is present (Fig. 14A).

Autozooids cylindrical with slightly convex frontal walls crossed by prominent growth ridges 20 to $50 \mu \mathrm{m}$ apart (Fig. 14B); autozooids longer in the central part of the colony, more crowded and shorter around the margins. Apertures oval in shape, slightly elongated distally, arranged in quincunx, some closed by terminal diaphragms; peristomes slightly raised, narrow (Fig. 14B). Pseudopores oval in shape, transversely elongate, closely spaced (Fig. 14D).

Gonozooids numerous, situated mostly in the marginal part of the colony, brood chamber roughly triangular or transversely oval in shape (Fig. 14A, C). Ooeciopore oval, slightly longer then wide, smaller that an autozooidal aperture (Fig. 14C). 
Remarks. - The specimens identified here as Hyporosopora cf. enstonensis have frontal walls covered by transverse ridges, as in the type material of this species from the Bathonian Hampen Marly Beds of Oxfordshire, England (see Pitt \& Thomas 1969, p. 33, pl. 1, fig. 1, pl. 4, figs 2-3). However, the Zalas specimens have longer frontal walls and growth-ridges that are less distinct and regular than in $H$. enstonensis. Another species described from Poland with growth-ridges on the colony surface is Hyporosopora baltovensis Hara \& Taylor, 1996 (see Hara \& Taylor 1996, pp. 95-98, figs 9-11, 13-18). In this species the ridges are discontinuous, irregularly spaced and 0.02-0.08 mm apart. Compared to $H$. cf. enstonensis, $H$. baltovensis has larger autozooidal apertures and ooeciopores.

Transverse ridges crossing the colony surface are found in some other Jurassic species, such as Mesenteripora undulata (Michelin, 1845) (see Walter 1970), Plagioecia rugosa (d'Orbigny, 1853) and Hyporosopora portlandica (Gregory, 1896) (see Taylor 1981, p. 864, figs 3-6), which are respectively Bathonian, Oxfordian and Tithonian in age. The presence of ridges in Jurassic bryozoans was discussed by Hara \& Taylor (1996) who concluded that the transversely ridged species seemed to be closely related and could be classified in the family Plagioeciidae (see Hara \& Taylor 1996).

\section{Genus Mesonopora Canu \& Bassler, 1929}

Type species. - Mesonopora concatenata (Reuss, 1867).

\section{Mesonopora walteri sp. nov.}

Figure 15A-D

Types. - Holotype: GIUS 8-3589-Z10/2 (Fig. 15A-D), paratype: GIUS 8-3589-M1.

Type locality. - Zalas Quarry, southern Poland.

Type horizon. - Callovian hardground, Middle Jurassic.

Etymology. - In honour of Bernard Walter, French researcher on Mesozoic bryozoans.

Material. - Two specimens encrusting bivalve shells: GIUS 8-3589-Z10/2 and GIUS 8-3589-M1.

Measurements. - Autozooid frontal wall length: 490-690 $\mu \mathrm{m}$; autozooid frontal wall width: 160-210 $\mu \mathrm{m}$; longitudinal apertural diameter: $110-125 \mu \mathrm{m}$; transverse apertural diameter: $75-87 \mu \mathrm{m}$; gonozooid total length: $1090 \mu \mathrm{m}$; brood chamber length: $580 \mu \mathrm{m}$; gonozooid width: $3850 \mu \mathrm{m}$; ooeciopore length: $90 \mu \mathrm{m}$; ooeciopore width: $60 \mu \mathrm{m}$; pseudopore length: $6-9 \mu \mathrm{m}$; pseudopore width: 7-10 $\mu \mathrm{m}$.
Diagnosis. - Mesonopora with a sheet-like colony having elongate autozooids with widely spaced apertures; brood chamber broad, transversely elongated with slightly curved distal margins; pseudopores semicircular.

Description. - Colony encrusting, sheet-like, bereniciform, multiserial, unilamellar, discoidal in outline (Fig. 15A). Autozooids elongate with slightly convex frontal walls; zooidal boundaries well marked, shallowly grooved. Peristomes distinct, tapering distally. Apertures longitudinally elongated, some closed by pseudoporous diaphragms (Fig. 15B), distantly spaced and not aligned radially. Pseudopores slightly wider than longer, semicircular in outline (Fig. 15D).

Gonozooids with flat proximal part and brood chamber that is transversely elongated, six times wider than long, inflated, the distal parts curving slightly towards the colony interior, margins intended by numerous neighbouring autozooids (Fig. 15C). Ooeciopore terminal, longitudinally elongated, oval in shape, smaller than an autozooidal aperture, situated on a short ooeciostome.

Remarks. - Mesonopora concatenata (Reuss, 1867), a species known from the Upper Bathonian of Normandy and England (Walter 1970) and the Upper Bathonian-Lower Callovian of Balin, Poland (Taylor 2009), has similarly broad gonozooids but differs from the new species in its characteristically closely spaced apertures aligned in radial rows, smaller and more curved brood chambers, and transversely elongated ooeciopore.

\section{Mesonopora aff. walteri sp. nov.} Figure 15E, F

Material. - One colony encrusting a bivalve shell, GIUS 8-3589-Z9/3.

Measurements. - Autozooid frontal wall length: 310-520 $\mu \mathrm{m}$; autozooid frontal wall width: 100-140 $\mu \mathrm{m}$; longitudinal apertural diameter: $90-125 \mu \mathrm{m}$; transverse apertural diameter: $62-87 \mu \mathrm{m}$; gonozooid total length: $650 \mu \mathrm{m}$; brood chamber length: $400 \mu \mathrm{m}$; gonozooid width: $1850 \mu \mathrm{m}$; ooeciopore length: $50 \mu \mathrm{m}$; ooeciopore width: $50 \mu \mathrm{m}$; pseudopore length: $5 \mu \mathrm{m}$; pseudopore width: $10 \mu \mathrm{m}$.

Remarks. - This taxon is similar to Mesonopora walteri sp. nov. described above but differs in having smaller autozooids and transversely elliptical pseudopores that are two times wider than long (Fig. 15F). Assuming that pseudopore characteristics are species specific (e.g., Taylor \& Zatoń 2008, Zaton \& Taylor 2009), then this colony could represent a distinct species of Mesonopora but additional specimens are needed to warrant introduction of a new species. 

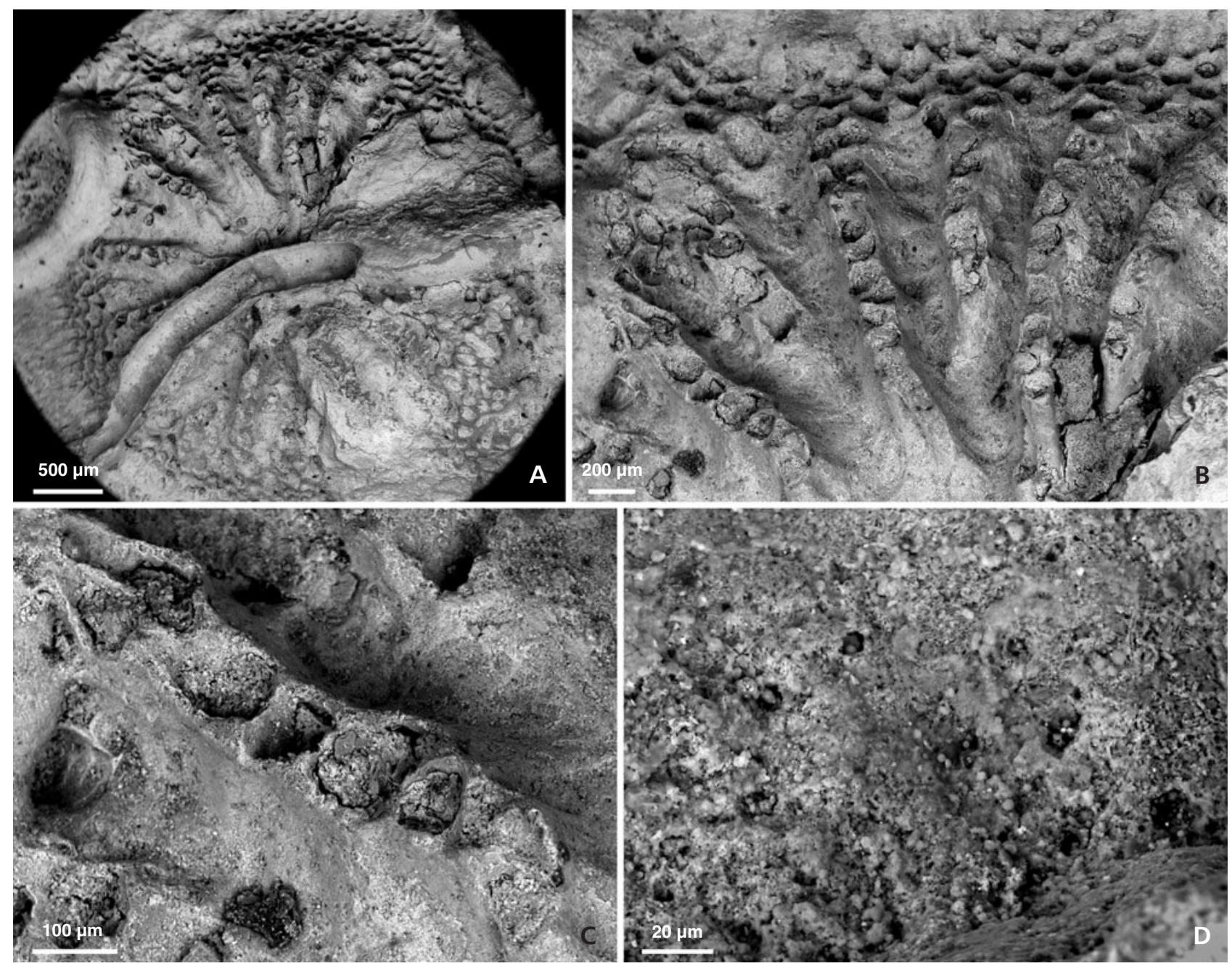

Figure 16. Theonoa minuta (Reuss, 1867) from the Callovian hardground of the Zalas Quarry, southern Poland, GIUS 8-3589-M15b. • A - fasciculate colony view; $\mathrm{B}$ - fascicles arrangement; $\mathrm{C}$ - autozooids; D - pseudopores.

Family Theonoidae Busk, 1859

\section{Genus Theonoa Lamouroux, 1821}

Type species. - Theonoa chlatrata Lamouroux, 1821 by monotypy.

\section{Theonoa minuta (Reuss, 1867)}

Figure 16A-D

1867 Pavotubigera minuta, Reuss, p. 3, pl. 2, fig. 8.

1970 Theonoa chlatrata Lamouroux. - Walter, p. 190 (partim), non pl. 19, figs $8,9,11$, non pl. 20, fig. 1 [= Theonoa chlatrata Lamouroux, 1821].

2009 Theonoa minuta (Reuss). - Taylor, p. 44, fig. 12A-F.

Material. - Three neighbouring colonies encrusting a bivalve shell, GIUS 8-3589-M15b.
Description. - Colonies encrusting, multiserial, unilamellar, circular in outline (Fig. 16A), small (3.6 mm in diameter), fasciculate. Fascicles uniserial in early astogeny, becoming multiserial; new fascicles arising through bifurcation or intercalation (Fig. 16B). Autozooids small with rounded-quadrate apertures $80-120 \mu \mathrm{m}$ in diameter (Fig. 16C). Gonozooids not observed. Pseudopores badly preserved but apparently subcircular in outline (Fig. 16D), about $8 \mu \mathrm{m}$ in diameter.

Remarks. - The species was revised by Taylor (2009) based on the original material of Reuss (1867) from Balin. The colonies from the Callovian of Zalas described here, although infertile, match the Balin type well. The Bathonian species Theonoa chlatrata Lamouroux, 1821, originally described from Normandy (Walter 1970), differs from $T$. minuta in developing larger colonies, autozooids and gonozooids (see also Taylor 2009). 


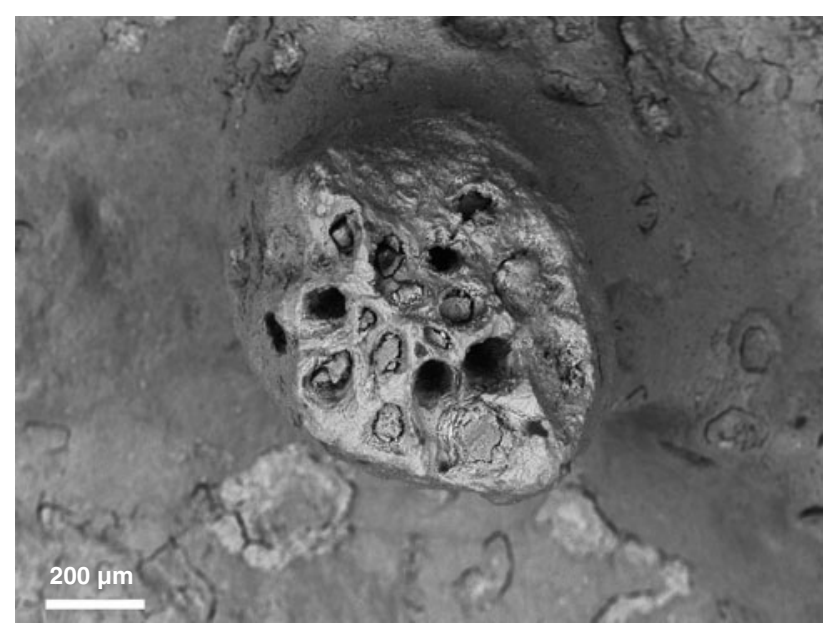

Figure 17. Undeterminable entalophorid base, GIUS 8-3589-Z9/1.

Family Entalophoridae Reuss, 1869

Entalophoridae gen. et. sp. indet. Figure 17

Material. - Six bases attached to bivalve shells, of which two have been SEMed: GIUS 8-3589-Z9/1-2.

Remarks. - The present material consists of poorly preserved bases of erect cyclostomes that are indeterminate at genus level. The absence of an axial lumen in the erect branches indicates that the specimens do not belong to the genus Entalophora itself (see Walter 1970, Taylor \& McKinney 2006, Zatoń \& Taylor, 2010).

Family Incertae sedis

"Berenicea" sp.

Figure 18A-D

Material. - Two colonies encrusting bivalve shells: GIUS 8-3589-Z11/3, GIUS 8-3589-Z7/1.

Description. - Colony encrusting, multiserial, sheet-like, unilamellar, subcircular in outline (Fig. 18A), about $4.5 \mathrm{~mm}$ in maximum diameter, thin with growing edge normally exposing only one generation of zooids, basal lamina not extending significantly beyond budding zone, pustules visible on basal walls of some new buds. Early astogenetic stages obscured by sediment.

Autozooids slender (Fig. 18B), up to $800 \mu \mathrm{m}$ long and attaining $140 \mu \mathrm{m}$ in maximum width close to the short preserved peristome. Apertures arranged quincuncially, longitudinally elongate, up to $100 \mu \mathrm{m}$ long by $70 \mu \mathrm{m}$ wide, some closed by terminal diaphragms (Fig. 18B). Frontal wall with transverse growth bands (Fig. 18B, C); pseudopores seemingly lacking (Fig. 18C, D). Gonozooids not observed.

Remarks. - In the absence of gonozooids, this form is assigned to the informal genus "Berenicea" following the recommendation of Taylor \& Sequeiros (1982). A remarkable feature of the two colonies from Zalas is their apparent lack of pseudopores. Other cyclostome species from Zalas show clear pseudopores, even when the surfaces of the colonies are only moderately well-preserved. One of the two specimens (GIUS 8-3589-Z11/3) exhibits particularly good preservation of the frontal walls, yet no pseudopores are visible. Cyclostome pseudopores can be sparse and are occasionally partly or completely occluded, as in Stomatopora cf. dichotomoides (d'Orbigny, 1850) described above, but in such instances they tend to be fully open and clearly visible at the growing edge, which is not the case in the Zalas "Berenicea". Two possibilities can be suggested: either the pseudopores in the Zalas forms are very sparsely distributed and have been overlooked, or they are absent altogether.

To our knowledge all post-Palaeozoic cyclostomes with exterior walls possess pseudopores. There are, however, Palaeozoic cyclostomes that lack pseudopores, including the Ordovician-Devonian genus Sagenella (Suborder Paleotubuliporina), which strongly resembles some post-Palaeozoic Berenicea-like cyclostomes except for the absence of pseudopores and gonozooids. The best-known species, Sagenella consimilis (Lonsdale), which occurs in the Wenlock of Britain and Gotland, Sweden, is superficially very similar to the Zalas forms of "Berenicea", although each zooid has a pair of minute, raised pores along the midline (see Brood 1975). It would be premature to assert a close affinity between the Zalas taxa and Palaeozoic Sagenella but further research is warranted to test the possibility that paleotubuliporine cyclostomes lacking pseudopores survived into the Jurassic.

Suborder Cerioporina Hagenov, 1851

Family Cavidae d'Orbigny, 1854

\section{Genus Ceriocava d'Orbigny, 1854}

\section{Ceriocava sp.}

Figure 19A, B

Material. - Several variably preserved colonies, including the figured specimen GIUS 8-3589-C/W-230/3.

Description. - Colonies dome-shaped, free-walled with 

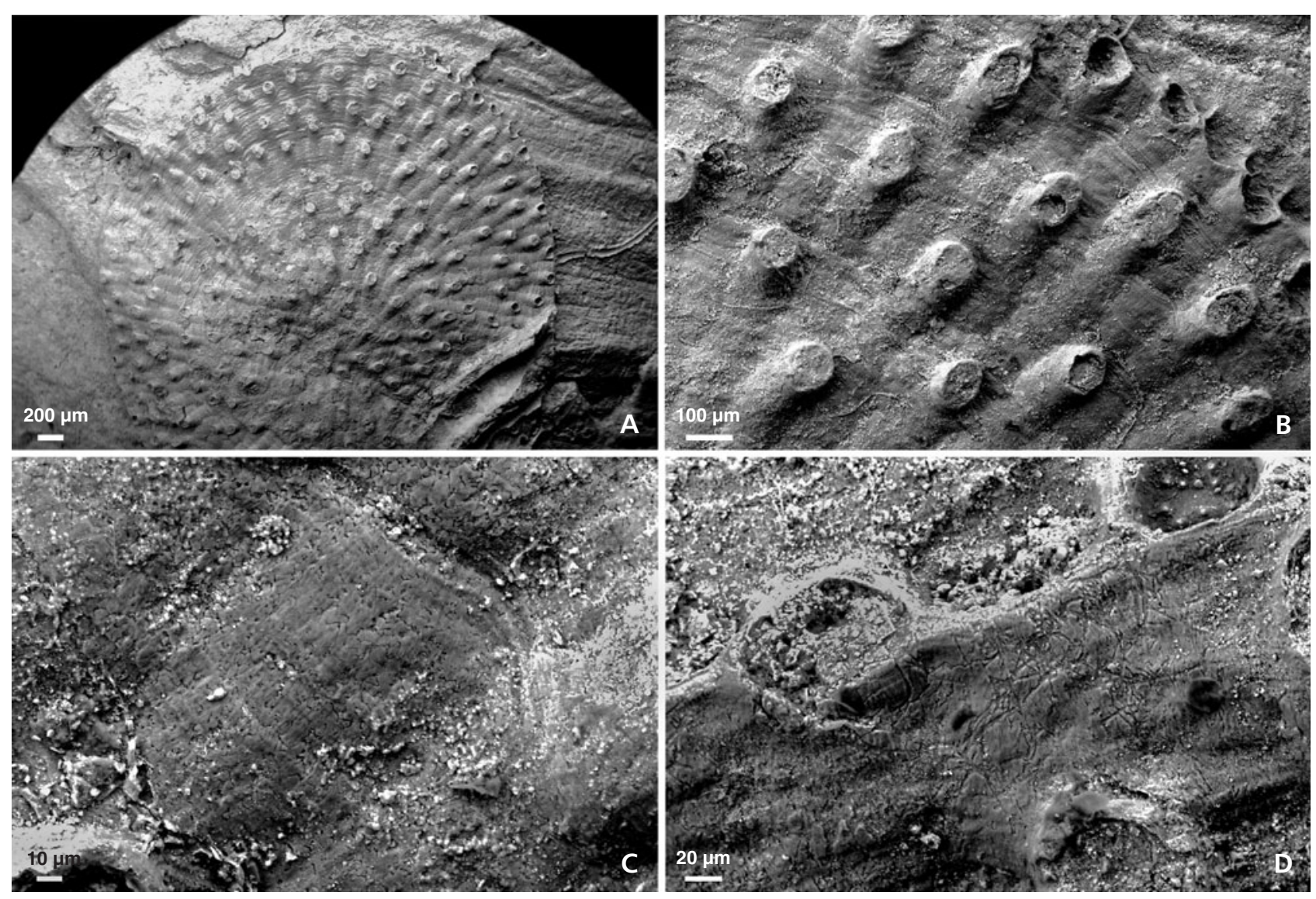

Figure 18. "Berenicea" sp., a bereniciform cyclostome of uncertain affinity from the Callovian hardground of the Zalas Quarry, southern Poland, GIUS 8-3589-Z11/3. • A - sheet-like colony view; B - autozooids; C, D - autozooidal frontal walls apparently devoid of pseudopores.

autozooids openings over entire upper surface (Fig. 19A). One colony preserves the ancestrula with a smooth, circular, bulbous protoecium $270 \mu \mathrm{m}$ in diameter (Fig. 19B), separated from the rest of the colony by a distinct constriction. Autozooids with rounded polygonal apertures and thick interzooidal walls giving the colony a characteristic honeycomb-like pattern (Fig. 19A). Gonozooids not observed.

Remarks. - Colony shape and autozooidal characteristics resemble other representatives of the genus (e.g., Walter 1970; Taylor 2009; Zatoń \& Taylor 2009, 2010). However, the lack of gonozooids precludes species identification. Thus, it cannot be determined whether the Zalas Callovian specimens represent the well-known species Ceriocava corymbosa (Lamouroux, 1821), or are a different species, as is also the case for Ceriocava specimens in the Upper Bajocian-Upper Bathonian of Poland (Zaton \& Taylor 2009, 2010). It is worth noting that the Upper Bathonian-Lower Callovian specimens of Ceriocava specimens from the nearby Balin locality (see Taylor 2009) lack gonozooids, making their assignment to Ceriocava corymbosa also uncertain.
Family Heteroporidae Waters, 1880

\section{Genus Ripisoecia Canu \& Bassler, 1922}

Ripisoecia conifera (Lamouroux, 1821)

Figure 19C, D

1821 Millepora conifera, Lamouroux, p. 87, pl. 83, figs 6-7.

1867 Heteropora conifera Lamouroux. - Reuss, p. 12 (partim), pl. 1, fig. 12, pl. 2, fig. 1 only.

1970 Ripisoecia conifera (Lamouroux). - Walter, p. 160, pl. 16, figs 6-12, pl. 17, figs 1, 2.

2009 Ripisoecia conifera (Lamouroux). - Taylor, p. 48, figs $13 \mathrm{~B}, 14 \mathrm{D}-\mathrm{F}$.

Material. - One colony encrusting a bivalve shell, GIUS 8-3589-Z7/2.

Description. - Colony globular, fungiform (Fig. 19C), $4 \mathrm{~mm}$ in diameter, attached to the substrate by a short stalk. Apertures rounded polygonal in outline, separated by thick interzooidal walls; autozooidal apertures up to $220 \mu \mathrm{m}$ in 

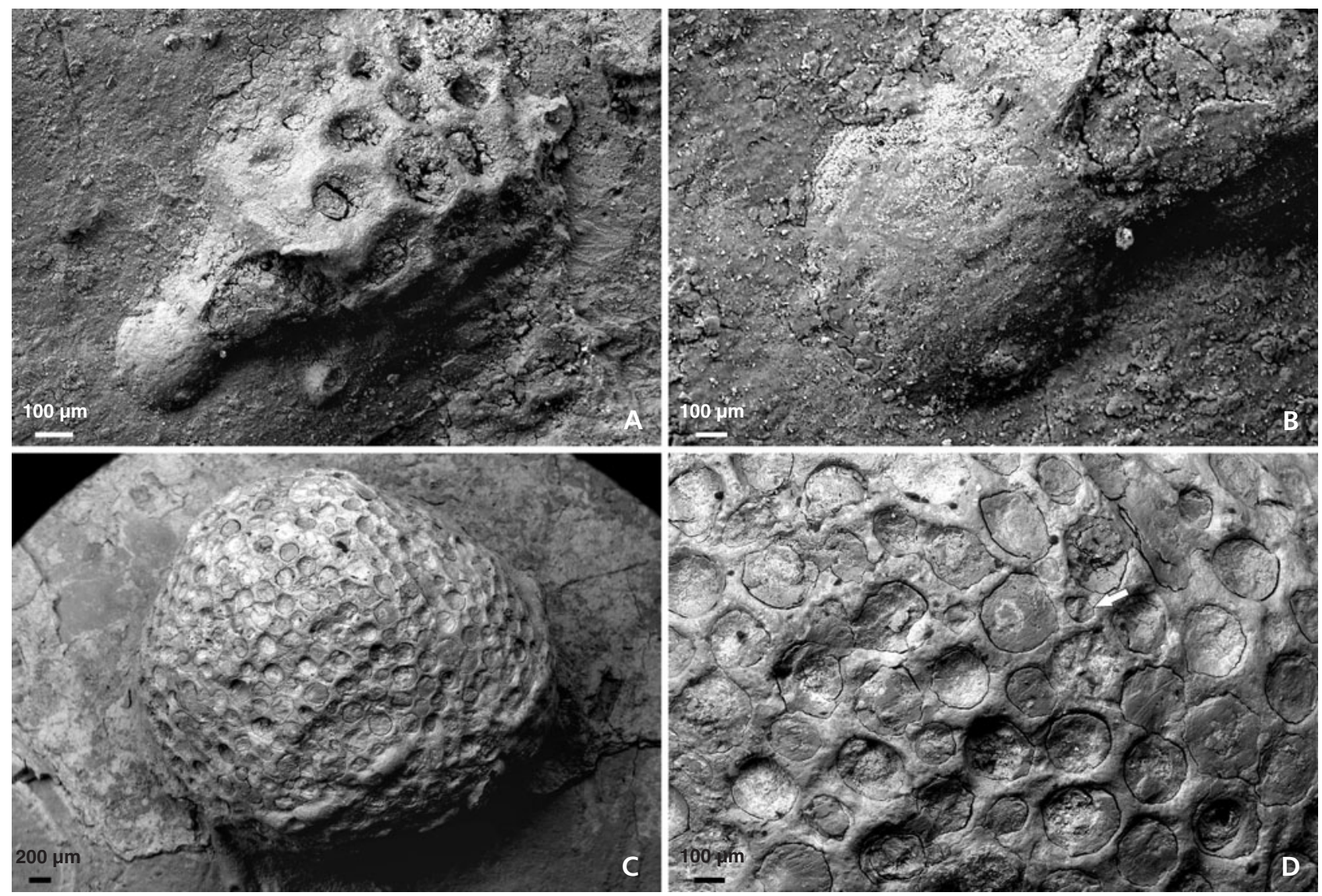

Figure 19. Ceriocava sp. (A, B) and Ripisoecia conifera (Lamouroux, 1821) (C, D) from the Callovian hardground of the Zalas Quarry, southern Poland. - A - juvenile colony; $\mathrm{B}$ - protoecium; $\mathrm{C}$ - dome-shaped colony; D - autozooidal apertures and smaller kenozooidal apertures (e.g., arrow). A, B - GIUS 8-3589-C/W-230/3; C, D - GIUS 8-3589-Z7/2.

diameter interspersed with smaller kenozooidal apertures up to $80 \mu \mathrm{m}$ (Fig. 19D).

Remarks. - This species was recorded from the classic locality at Balin, southern Poland by Reuss (1867), revised by Taylor (2009). It differs from the related Ceriocava in its globular to fungiform colonies and dimorphic apertures. Gonozooids have not been seen in either the Balin or Zalas colonies.

\section{Discussion and conclusions}

As in other Jurassic cyclostome bryozoan assemblages, the fauna from the Callovian of Zalas is represented by three dominant encrusting colony-forms: uniserial branching runners, oligoserial branching ribbons, and multiserial sheets. The runner-like colonies are fugitive strategists, which are well-adapted to locating spatial refuges on the substrate (see Buss 1979, Jackson 1979, Taylor 1999). They are mainly represented by species of Stomatopora. In contrast, the sheet-like colonies are better adapted to retaining the sub- strate space they occupy (see Jackson 1979, Taylor 1999) and consist of such bereniciform genera as Microeciella, Hyporosopora, Mesonopora and Reptomultisparsa, plus generically indeterminate forms assignable to the form-genus "Berenicea". Oligoserial branching colonies, some of which can be assigned to Oncousoecia, have an intermediate morphological strategy. Also present at Zalas are the massive, often multilayered, dome-shaped and fungiform genera of Ceriocava and Ripisoecia, respectively. The fasciculate genus Theonoa and indeterminate "entalophorids" are minor constituents in the Zalas assemblage.

Bereniciform cyclostomes, although often numerous on a given hard substrate, are mainly represented by infertile colonies that are indeterminate at genus-level. For example, of the 357 bereniciform colonies from the Callovian of Zalas examined by Zatoń et al. (2011), only 37 (10\%) were fertile. This pattern is repeated in other Jurassic assemblages (e.g., Zatoń \& Taylor 2009, 2010; Hara 2007; Hara \& Taylor 2009), impacting analyses of assemblage diversity.

The Callovian cyclostome assemblage described here from Zalas is represented by at least twenty-two taxa. Co- 
incidentally, the cyclostome fauna from the condensed Upper Bathonian-Lower Callovian Oolite at the nearby locality of Balin contains a very similar number (23) of species (Taylor 2009). In the context of the Jurassic, Zalas and Balin are diverse: few other Jurassic bryozoan faunas contain more than 20 species (Taylor \& Wilson 1999). Another diverse Callovian cyclostome bryozoan fauna comes from the Moscow region of Russia where 20 species were described by Gerasimov (1955) and are currently under revision by Viskova (e.g., Viskova 2006, 2007, 2008, 2009).

The Balin Oolite, although containing some genera (Multisparsa, Idmonea and Mesenteripora) not present in the Zalas assemblage also possesses a few species in common, such as Hyporosopora tenera, Ripisoecia conifera and Theonoa minuta. The Zalas stomatoporids, although only identifiable with uncertainty, are also very similar to those from Balin. Erect "entalophorids" that are unknown from the Balin assemblage occur in the Zalas bryozoan assemblage (Zatoń et al. 2011). Hyporosopora tenera and other species similar to those previously described from somewhat older Bathonian strata of the Polish Jura (see Zatoń \& Taylor 2009, 2010), such as Microeciella aff. annae, M. cf. maleckii and Reptomultisparsa aff. kawodrzanensis, occur in the Callovian assemblage of Zalas.

Differences in species composition between Balin and Zalas may reflect different environmental settings (shallower water in Balin than Zalas). However, it must also be stressed that a large number of cyclostome colonies from Zalas are infertile and thus many other genera and species may have existed that have gone unrecognized, causing true diversity to be underestimated.

Both environmental (unchanging salinity, reduced algal cover) and depositional (reduced sedimentation rate in a deeper setting) conditions were important for the establishment of diverse sclerobiont communities in the Callovian of the Zalas area (Zaton et al. 2011). The prolonged interval of non-deposition during hardground formation (e.g., Giżejewska \& Wieczorek 1976, Matyja 2006, Dembicz \& Praszkier 2007) was one of the most important factors, resulting in the presence of abundant secondary hard substrates for colonization. A problem yet to be resolved is how so many morphologically similar bereniciform taxa were able to coexist in Jurassic bryozoan assemblages, including that described here from Zalas. These forms exhibit a common strategy for utilizing substrate space ( $c f$. the refuge-seeking strategy of Stomatopora; see Taylor 1979, 1999), and have similar life-histories (see McKinney \& Taylor 1997). In addition the sizes of the zooids spans too narrow a range to support significant niche partitioning by food particle size. The functional significance of differences in pseudopore morphology between cyclostome species has yet to be understood.

As runners such as Stomatopora are considered to be well-adapted to low nutrient environments (Okamura et al.
2001; see also Sogot et al. 2013), the clear predominance of bereniciform colonies over the refuge-seeking runners (see Zatoń et al. 2011, table 1) may be indicative of a rather eutrophic conditions prevailing in the basin during the times of the hardground formation. Similar conclusions, as based on the presence of an abundant and diverse polychaete tubes, oysters and bryozoans, were reached by Zaton et al. (2011) on the basis of criteria worked out earlier in a Recent sclerobiont biota by Lescinsky et al. (2002).

The strikingly patchy distribution of Jurassic bryozoan faunas in time and space (Taylor \& Ernst 2008) makes descriptions of faunas such as from Zalas especially important for improving our knowledge of evolutionary and diversity patterns during this unique time when cyclostome bryozoans achieved dominance before the advent of the cheilostomes. The assemblages from Zalas and Balin contain the highest diversity of Callovian cyclostome bryozoans known to date and thus serve as a reference for diversity comparisons with subsequent work on Callovian assemblages.

\section{Acknowledgments}

This research was possible due to the financial support of the Faculty of Earth Sciences to MZ. Laís Ramalho and Kamil Zágoršek commented on the early version of the manuscript, providing numerous remarks and corrections that are greatly appreciated. We are grateful to Roger J. Cuffey and Eckart Håkansson, the journal reviewers, for further useful remarks and comments that improved the present article. We also thank Mrs Barbara Ruszkiewicz for taking the photographs of the bryozoan-encrusted shells.

\section{References}

BASSLER, R.S. 1935. Bryozoa. Generum et Genotyporum. Index et Bibliographica, 1-229. In Quenstedt, W. (ed.) Fossilium Catalogus I. Animalia. Vol. Part 67. W. Junk, s'Gravenhage.

Bronn, H.G. 1825. System der urweltlichten Pflanzenthiere durch Diagnose, Analyse und Abbildung der Geschlechter erläutert. 47 pp. Mohr, Heidelberg.

Brood, K. 1975. Cyclostomatous Bryozoa from the Silurian of Gotland. Stockholm Contributions in Geology 28, 45-119.

Busk, G. 1852. An account of the Polyzoa and Sertularian Zoophytes collected in the voyage of the Rattlesnake on the coast of Australia and the Louisiade Archipelago, 343-402. In MacGillivray, J. (ed.) Narrative of the Voyage of H.M.S. Rattlesnake, commanded by the late Captain Owen Stanley, during the years 1846-1850,1. Boone, London.

Busk, G. 1859. A monograph of the fossil Polyzoa of the Crag. 136 pp. Palaeontographical Monograph, London.

DOI 10.5962/bhl.title.2037

Buss, L.W. 1979. Habitat selection, directional growth and spa- 
tial refuges: why colonial animals have more hiding places, 459-497. In Larwood, G. \& Rosen, B.R. (eds) Biology and Systematics of Colonial Organisms. Systematic Association Special Volume 11. Academic Press, London \& New York.

CANu, F. 1918. Les ovicelles des Bryozoaires cyclostomes. Études sur quelques familles nouvelles et anciennes. Bulletin de la Société Géologique de France 4, 324-335.

CANu, F. \& BassLer, R.S. 1922. Studies on the cyclostomatous Bryozoa. Proceedings of the United States National Museum 61, 1-160. DOI 10.5479/si.00963801.61-2443.1

CANU, F. \& Bassler, R.S. 1929. Etudes sur les ovicelles des Bryozoaires jurassiques. Bulletin de la Société Linnéenne de Normandie 8, 113-131.

Dembicz, K. \& Praszkier, T. 2007. Kelowej południowowschodniej części Jury Krakowsko-Częstochowskiej. Tomy Jurajskie 4, 71-76.

GERASIMOv, P.A. 1955. Index fossils of the Mesozoic of the Central Regions of the European part of the USSR. Part II. Echinodermata, Crustacea, Vermes, Bryozoa, and Anthozoa of the Jurassic Deposits. 90 pp. Gosgeolyekhizdat, Moscow. [in Russian]

GiżejewsKa, M. \& WieczoreK, J. 1976. Remarks on the Callovian and Lower Oxfordian of the Zalas Area (Cracow Upland, Southern Poland). Bulletin de l'Académie Polonaise des Sciences, Série des Sciences de la Terre 24, 167-175.

Gregory, J.W. 1896. A revision of the British Jurassic Bryozoa. Part III. The genus Berenicea. Annals and Magazine of Natural History, Series $617,41-49$.

Hagenow, F. von 1851. Die Bryozoen der Maastrichter Kreidebildung. 111 pp. Fischer, Cassel.

HARA, U. 2007. Charakterystyka jurajskich mszywiołów południowej Polski w aspekcie warunków paleośrodowiska i biogeografii. Przeglad Geologiczny 55, 54-60.

HARA, U. \& TAYLOR, P.D. 1996. Jurassic bryozoans from Bałtów, Holy Cross Mountains, Poland. Bulletin of The Natural History Museum, London (Geology Series) 52, 91-102.

Hara, U. \& TAYlor, P.D. 2009. Cyclostome bryozoans from the Kimmeridgian (Upper Jurassic) of Poland. Geodiversitas 31, $555-575$. DOI $10.5252 / \mathrm{g} 2009 \mathrm{n} 3 \mathrm{a} 4$

JABlONSKi, D., LidgaRd, S. \& TAYloR, P.D. 1997. Comparative ecology of bryozoan radiations: origin of novelties in cyclostomes and cheilostomes. Palaios 12, 505-523. DOI $10.2307 / 3515408$

JACKSON, J.B.C. 1979. Morphological strategies of sessile animals, 499-555. In LARwood, G. \& Rosen, B.R. (eds) Biology and Systematics of Colonial Organisms. Systematic Association Special Volume 11. Academic Press, London \& New York.

Lamouroux, J.V. 1821. Exposition méthodique des genres de l'ordre des polpiers. 115 pp. Agasse, Paris.

Lescinsky, H.L., EdINGER, E. \& Risk, M.J. 2002. Mollusc shell encrustation and bioerosion rates in a modern epeiric sea: Taphonomy of experiments in the Java Sea, Indonesia. Palaios 17, 171-191.

DOI 10.1669/0883-1351(2002)017<0171:MSEABR>2.0.CO;2

Matyja, B.A. 2006. Stop A17 - Zalas Quarry - Callovian transgressive to condensed pelagic deposits, Lower to lowermost Middle Oxfordian deposits of sponge megafacies, 70-72. In Wierzbowski, A., Aubrecht, R., Golonka, J., Gutowski, J.,
Krobicki, M., Matyja, B.A., Pieńkowski, G. \& Uchman, A. (eds) Jurassic of Poland and adjacent Slovakian Carpathians. Field trip guidebook of $7^{\text {th }}$ International Congress on the Jurassic System Poland, Kraków, September 6-18, 2006.

Mangold, C., Marchand, D., Thierry, J. \& TARKowski, R. 1996. Les ammonites de l'oolite de Balin (Pologne); nouvelles données réinterprétation stratigraphique. Revue de Paléobiologie $15,55-77$.

McKinney, F.K. \& TAYloR, P.D. 1997. Life histories of some Mesozoic encrusting cyclostome bryozoans. Palaeontology 40, 515-556.

Michelin, H. 1841-1848. Iconographie Zoophytologique, description par localités et terrains des polypiers fossiles de France et pays environnants. 348 pp. Bertrand, Paris.

Nawrocki, J., Lewandowska, A. \& Fanning, M. 2007. Wiek izotopowy a wiek paleomagnetyczny ryodacytów z Zalasu koło Krakowa (S Polska). Przegląd Geologiczny 55, 475-478.

OkAmura, B., HaRmelin, J.-G. \& JACKSON, J.B.C. 2001. Refuges revisited: Enemies versus flow and feeding as determinants of sessile animal distribution and form, 61-93. In JACKSON, J.B.C., Lidgard, S. \& McKinney, F.K. (eds) Evolutionary Patterns: Growth, Form and Tempo in the Fossil Record. University of Chicago Press.

Orbigny, A. D' 1850. Prodrome de paléontologie stratigraphique universelle des animaux mollusques et rayonnés. Tome 1. 394 pp. Masson, Paris. DOI 10.5962/bhl.title.62810

OrbignY, A. D' 1851-1854. Paléontologie Francaise, Terrains Crétacé. 5 Bryozoaires. 1192 pp. Masson, Paris.

Pergens, E. \& Meunier, A. 1886. La faune des Bryozoaires garumniens de Faxe. Annales de la Société Royale Malacologique de Belgique 12, 181-242.

Pitt, L.J. \& Thomas, H.D. 1969. The Polyzoa of some British Jurassic clays. Bulletin of the British Museum (Natural History), Geology Series 18, 29-38.

Reuss, A.E. 1867. Die Bryozoen, Anthozoen und Spongiaren des braunen Jura von Balin bei Krakau. Denkschriften der Kaiserlichen Akademie der Wissenschaften, Wien, Mathematischnaturwissenschaftliche Klasse 27, 1-26.

Reuss, A.E. 1869. Palaontologischen Studien uber die alteren Tertiarschichten der Alpen. II. Abtheilung. Die Fossilen Anthozoen und Bryozoen der Schichtengruppe von Crosara. Denschriften der Kaiserlichen Akademie der Wissenschaften, Wien, Mathematisch-naturwissenschaftliche Klasse 29, 215-298.

Sogot, C.E., Harper, E.M. \& TAYlor, P.D. 2013. Biogeographical and ecological patterns in bryozoans across the Cretaceous-Paleogene boundary: Implications for the phytoplankton collapse hypothesis. Geology 41, 631-634. DOI 10.1130/G34020.1

TAYLOR, P.D. 1979. Functional significance of contrasting colony form in two Mesozoic encrusting bryozoans. Palaeogeography, Palaeoclimatology, Palaeoecology 26, 151-158. DOI 10.1016/0031-0182(79)90146-9

TAYLOR, P.D. 1980. Two new Jurassic Bryozoa from southern England. Palaeontology 23, 699-706.

TAYLOR, P.D. 1981. Bryozoa from the Jurassic Portland Beds of England. Palaeontology 24, 863-875.

TAYLOR, P.D. 1984. Reptomultisparsa d'Orbigny, 1853 (Bryozoa, Cyclostomata): request for the designation of a type-spe- 
cies. Z.N.(S.) 2400. Bulletin of Zoological Nomenclature 41, 77-79.

TAYLor, P.D. 1999. Bryozoa, 623-646. In SAVAzZi, E. (ed.) Functional morphology of the invertebrate skeleton. Wiley, Chichester.

TAYLOR, P.D. 2009. Bryozoans from the Middle Jurassic of Balin, Poland: a revision of material described by A.E. Reuss (1867). Annalen des Naturhistorisches Museum in Wien 110 A, 17-54.

TAYlor, P.D. \& ERnst, A. 2008. Bryozoans in transition: the depauperate and patchy Jurassic biota. Palaeogeography, Palaeoclimatology, Palaeoecology 263, 9-23.

DOI 10.1016/j.palaeo.2008.01.028

TAYLOR, P.D. \& LARWOOD, G.P. 1990. Major evolutionary radiations in the Bryozoa, 209-233. In TAYLOR, P.D. \& LARWOOD, G.P. (eds) Major evolutionary radiations. Systematics Association, London.

TAYLOR, P.D. \& McKinNEY, F.K. 2006. Cretaceous Bryozoa from the Campanian and Maastrichtian of the Atlantic and Gulf Coastal Plain, United States. Scripta Geologica 132, 1-346.

TAYloR, P.D. \& SEqueiros, L. 1982. Toarcian bryozoans from Belchite in north-east Spain. Bulletin of the British Museum (Natural History), Geology Series 37, 117-129.

TAYLOR, P.D. \& Wilson, M.A. 1999. Middle Jurassic bryozoans from the Carmel Formation of southwestern Utah. Journal of Paleontology 73, 816-830.

TAYLOR, P.D. \& ZATON, M. 2008. Taxonomy of the bryozoan genera Oncousoecia, Microeciella and Eurystrotos (Cyclostomata: Oncousoeciidae). Journal of Natural History 42, 2557-2574. DOI 10.1080/00222930802277640

Viskova, L.V. 2006. Bryozoans of the genera Stomatopora Bronn and Stoporatoma gen. nov. (Stenolaemata) from the Middle Jurassic of Moscow City and the Moscow region. Paleontological Journal 40, 425-430.

DOI 10.1134/S0031030106040071
Viskova, L.V. 2007. New bryozoans (Stenolaemata) from the Middle Jurassic of Moscow City and the Moscow region. Paleontological Journal 41, 46-55. DOI 10.1134/S0031030107010054

VisKovA, L.V. 2008. New stenolaematous bryozoans from the Jurassic of Central European Russia (Moscow City and the Moscow and Kostroma Regions). Paleontological Journal 42, 149-158. DOI 10.1007/s11492-008-2005-8

Viskova, L.V. 2009. New species of stenolaemate bryozoans from the Jurassic of the Moskov and Saratov regions (Russia). Paleontological Journal 43, 408-417. DOI 10.1134/S003103010904008X

WaAgen, W. 1867. Über die Zone des Ammonites sowerbyi. Geognostisch-Paläontologische Beiträge von Dr. E. W. Benecke, München 1, 507-668.

Walter, B. 1970. Les bryozoaires jurassiques en France. Documents des Laboratoires de Géologie de la Faculté des Sciences de Lyon 35 [for 1969], 1-328.

WAters, A.W. 1880. Note on the genus Heteropora. Annals and Magazine of Natural History 5(6), 156-157.

DOI 10.1080/00222938009458909

WEEDON, M.J. \& TAYLOR, P.D. 1997. Skeletal ultrastructure in some tubuliporine cyclostome bryozoans. Acta Zoologica 78, 107-122. DOI 10.1111/j.1463-6395.1997.tb01132.x

Zatoń, M. \& TAYLOR, P.D. 2009. Middle Jurassic cyclostome bryozoans from the Polish Jura. Acta Palaeontologica Polonica 54, 267-288. DOI 10.4202/app.2008.0088

ZAtoń, M. \& TAYLOR, P.D. 2010. Bathonian (Middle Jurassic) cyclostome bryozoans from the Polish Jura. Bulletin of Geosciences 85, 275-302. DOI 10.3140/bull.geosci.1184

ZatoŃ, M., Wilson, M.A. \& Zavar, E. 2011. Diverse sclerozoan assemblages encrusting large bivalve shells from the Callovian (Middle Jurassic) of southern Poland. Palaeogeography, Palaeoclimatology, Palaeoecology 307, 232-244. DOI 10.1016/j.palaeo.2011.05.022 